\title{
STATUTORY AND CONTRACTUAL RESTRICTIONS ON THE RIGHT TO STRIKE DURING THE TERM OF A COLLECTIVE BARGAINING AGREEMENT*
}

CoNTRACTUAL restrictions on the right of a union to strike during the term of the collective bargaining agreement play a vital role in the reduction of economic conflict. But despite legislative and judicial efforts to encourage the peaceful settlement of labor disputes by rendering the labor agreement more binding, ${ }^{1}$ the operative effect of contractual strike restrictions remains largely undefined; for although these restrictions may often be tied to or dependent upon arbitration procedures, there is no rational basis for concluding, as has Justice Douglas in dictum, ${ }^{2}$ that in every case the no-strike clause is given in exchange for arbitration. ${ }^{3}$ Even were these provisions always bargained for

*An earlier version of this Comment was submitted in satisfaction of the writing requirement of the Yale Law School's Divisional Program, Labor Law Division, 1960-1961. The Law Journal wishes to thank Professors Clyde W. Summers and Harry H. Wellington for bringing this paper to the Editors' attention.

1. Legislative efforts to develop an effective federal labor law governing the making and enforcing of the collective bargaining agreement are manifest by the imposition on both Iabor and management of a mandatory duty to bargain in good faith, Labor Management Relations Act, 61 Stat. 136 (1947), as amended, 29 U.S.C. $\S \S 8(a)(5), 8(b)$ (3), 8(d) (1958) [hereinafter cited as LMRA] and the opening of federal courts to suits alleging breach of the collective agreement, LMRA $\$ 301$ :

Suits for violation of contracts between an employer and a labor organization representing employees in an industry affecting commerce as defined in this Act, or between any such labor organizations, may be brought in any district court of the United States having jurisdiction of the parties, without respect to the amount in controversy or without regard to the citizenship of the parties.

See also LMRA $\S 203$ (d).

By its construction of $\S 301$ the Supreme Court has made it clear that there is to be a strong presumption favoring arbitrability of grievances, United Steelworkers v. American Mfg. Co., 363 U.S. 564 (1960) (compelling arbitration and excluding consideration by the court of the merits of the claim), United Steelworkers v. Warrior \& Gulf Nav. Co., 363 U.S. 574 (1960) (compelling arbitration by resolving all doubts in favor of coverage by the arbitration clause); and the validity of arbitrator's awards: United Steelworkers v. Enterprise Wheel \& Car Corp., 363 U.S. 593 (1960) (granting specific performance of an arbitration award).

2. Textile Workers Union v. Lincoln Mills, 353 U.S. 448, 455 (1957) ; United Steelworkers v. American Mfg. Co., 363 U.S. 564, 567 (1960) ; United Steelworkers v. Warrior \& Gulf Nav. Co., 363 U.S. 574, 578 n.4 (1960) ; [Warrior \& Gulf case above only quotes from Lincoln Mills at $578 \mathrm{n.4}$ : these are all by Douglas and insofar as the statement in text is repeated in two opinions, perhaps the word should be "dicta"].

3. For a discussion of arbitration as the "quid pro quo" of the no-strike clause, see Givens, Section 301, Arbitration and the No-strike Clanse, 11 LAB. L.J. 1005 (1960).

On the employment of quid pro quo in standard contract usage see 1 CorBIN, Contracts $\$ \S 109,117$ (1950). "A quid pro quo is the antithesis of something for nothing. It expresses the idea of a bargain-an exchange of this for that." Id. § 117. Cf. Fulda, The No Strike 
together, the further conclusion that one limits the scope of the other need not follow as a matter of law.4

A more meaningful analysis of the function of the no-strike clause requires an analysis of the intent of the parties and the interrelation of the various provisions of the collective agreement in the light of judicially and legislatively formulated federal labor law and policy. This Comment will therefore examine the origin and scope of statutory as well as contractual restrictions on the union's right to strike during the term of the collective agreement. It will focus on implied as well as express no-strike limitations and explore the relationship between arbitration and statutory limitations on the right to strike on the one hand and arbitration and contractual no-strike provisions on the other.

\section{Statutory Restrictions on the Right to Strike}

The duty to bargain in good faith imposed on the union by section 8 (b) (3) ${ }^{5}$ of the Taft-Hartley Act carries with it certain restrictions on the union's right to strike during the term of the collective agreement. Section $8(d)$ defines the concept of collective bargaining to include ". . . the negotiation of an agreement, or any question arising thereunder." This language clearly envisions the settlement of grievances between the parties during the life of the contract as an element in a continuing process of negotiation. It can be argued that use of economic force is incompatible with the orderly settlement

Clause, 21 Geo. WASH. L. REV. 127 (1952) : “. . no-strike clauses and arbitration clauses must be considered together because the latter constitutes the consideration for the surrender of the strike weapon." Id. at 164.

4. It is true that contractual no-strike clauses often specifically refer to or carry some discernible link to the contracts grievance machinery. See, e.g., United Steelworkers v. American Mfg. Co., 363 U.S. 564, 565 (1960), where the union's no-strike pledge was conditional upon the employer's abiding by arbitration awards; UAW v. Benton Harbor Indus., 242 F.2d 563 (6th Cir. 1957), cert. denied, 355 U.S. 814 (1957) (“. . . there shall be no strike ... on the part of the Union ... and there shall be no lockout on the part of the Company .... The parties shall in all instances resort to the following steps of the grievance procedure."). Id. at 538. But Justice Douglas seems to recognize that a broad no-strike clause may co-exist in an agreement with provisions specifically excluding certain grievances from the bargained-for arbitration mechanism. United Steelworkers v. Warrior \& Gulf Nav. Co., 363 U.S. 574, 583 (1960).

5. LMRA $\S 8(b)(3)$ : "[It shall be an unfair labor practice for a labor organization or its agents] to refuse to bargain collectively with an employer ...." This section must be read concurrently with $\S 8$ (d), defining the duty to bargain. See note 13 infra.

On the good faith bargaining obligation of the union see Cox, The Duty to Bargain in Good Faith, 71 HaRv. L. REv. 1401 (1958).

6. LMRA \& 8(d):

For the purposes of this section, to bargain collectively is the performance of the mutual obligation of the employer and the representative of the employers to meet at reasonable times and confer in good faith with respect to wages, hours, and other terms and conditions of employment, or the negotiation of an agreement, or any question arising thereunder. ... 
of grievances and, therefore, any strike which involves a question arising under the contract evidences a refusal to bargain in good faith and consequently constitutes a section 8(b) (3) lack of good faith unfair labor practice. ${ }^{7}$ This position seems untenable, however, in light of the Supreme Court's decision in NLRB v. Insurance Agents ${ }^{8}$ which held that union activity assumed to be unprotected under section 7 , in this instance a slowdown, did not constitute a per se section 8(b) (3) violation even though the activity occurred while the parties were negotiating a new contract. ${ }^{9}$ Because section 8 (d) does not distinguish between negotiation of questions arising under an existing contract and the negotiation of a new contract, it would seem to follow that strike activity, whether it be protected or unprotected, can not alone constitute an unfair labor practice under section 8(b) (3).

The Court's opinion in Insurance Agents, however, should not preclude the Board from considering such a strike to be evidence of a failure to bargain under section 8 (b) (3) where it is not the sole evidence adduced to support the finding. ${ }^{10}$ The statement of the Court that ". . . there is simply no inconsistency between the application of economic pressure and good-faith collective bargaining,"11 was made in the context of the Board's attempt to equate such pressure with a per se violation of section $8(\mathrm{~b})(3)$. The Court, in fact, seemed to recognize that a strike might evidence a lack of good faith bargaining when it cited Personal Products ${ }^{12}$ as "... [a] case of a union which was using economic pressure against an employer in a bargaining situation without identifying what its bargaining demands were-a matter which can be viewed quite differently in terms of an 8 (b) (3) violation from the present case." ${ }^{13}$ Thus, if the Board determines that a union is striking over a dispute

7. See International Union, UMW, 117 N.L.R.B. 1095 (1957), enforcement denied sub nom. International Union, UMW v. NLRB, 257 F.2d 211 (D.C. Cir. 1958).

8. 361 U.S. 477 (1960).

9. Id. at 480 :

... the union's harassing tactics involved activities by the member agents such as these: refusal for a time to solicit new business, refusal (after the writing of new business was resumed) to comply with the company's reporting procedures; refusal to participate in the company's "May Policy holders' Month Campaign"; reporting late at district offices the days the agents were scheduled to attend them, and refusing to perform customary duties at the offices, instead engaging there in "sit-inmornings," "doing what comes naturally" and leaving at noon as a group. ...

10. Since the majority opinion in Insurance Agents was directed at the Board's characterization of the union's conduct as a per se unfair labor practice the proper disposition of the case would seem to be that suggested by Justice Frankfurter in his concurring opinion-remand to the Board, rather than the majority's approach of affirming the Court of Appeals' refusal to enforce the Board's order.

11. 361 U.S. at $494-95$ (1960).

12. 108 N.L.R.B. 743 (1954), aff'd in part sub nom. Textile Workers Union v. NLRB, 227 F.2d 409 (D.C. Cir. 1955), cert. denied, 352 U.S. 864 (1956).

13. 361 U.S. at 491 and n.15.

The union in Personal Products engaged in various activities of a harassing nature at a time when a drop in production would have seriously affected the company's profits. The 
which is being processed through the grievance-settling machinery established in the collective bargain and also discovers some other indicia of bad faith, such as delay of the grievance procedure, it could, consistently with Insurance Agents, find a section 8(b) (3) unfair labor practice..$^{14}$

A more difficult problem is presented when the union strikes over a grievance which involves a question arising under the contract without first invoking the contractual grievance procedure. The Board would not seem to be precluded by the Insurance Agents doctrine from finding such action violative of section 8 (b) (3), since union failure to invoke the contract's grievance procedure constitutes conduct, in addition to the strike, evidencing lack of good faith. ${ }^{15}$ Doubt is cast upon the validity of such a finding, however, by language of the Court of Appeals for the District of Columbia in United Mine Workers v. $N L R B,{ }^{16}$ reversing a Board finding that a strike over arbitrable grievances was a strike in derogation of the contract and consequently an unfair labor practice under section 8 (b) (3). ${ }^{17}$ According to the court, the strike was neither in breach of contract nor an unfair labor practice, despite the failure to invoke the grievance procedure, since the parties had not reincorporated a previously included express no-strike clause into the agreement. ${ }^{18}$ While specifically declining to decide whether a breach of contract could, "merely as such, be regarded as an unfair labor practice,"19 the court quoted from the legislative history of Taft-Hartley to show that the Board must support "a heavy burden of persuasion" before it could treat a violation of a term of a collective contract, "even a term providing for the settlement of grievances by arbitration," as an unfair labor practice. ${ }^{20}$ Where the Board can not support this burden, however, it would seem unreasonable to preclude it from considering the union's failure to attempt to settle a dispute through the contractual grievance procedure as one element of bad faith bargaining..21 Admittedly section 8(d) places no affirmative duty on the parties to use one mode of negotiation in preference to another. But this does not mean that a party's fulfillment of its statutory duty to bargain in good faith should not be measured

Board found that "the Employer was not informed of any specific demands which these tactics were designed to enforce nor what concessions it could make to avoid them." 108 N.L.R.B. at 746.

14. This reasoning draws support from the Court's recognition of the Board's power to draw inferences from the "conduct of the parties as a whole." 361 U.S. at 498.

15. Cf. note 14 supra; International Union, UMW, 117 N.L.R.B. 1095, 1118-21 (1957), enforcement denied sub nom. International Union, UMW v. NLRB, 257 F.2d 211 (D.C. Cir. 1958).

16. 257 F.2d 211 (D.C. Cir. 1958).

17. 117 N.L.R.B. 1095 (1957).

18. 257 F.2d at 216-18.

19. Id. at 218.

20. Id. at 215 .

See 1 U.S.N.L.R.B., Legislative History of the Labor Management Relations Acr 114, 239, 545-46 (1947) [hereinafter cited as LEG. HIST.].

21. See note 14 supra. 
in part by its willingness to invoke the settlement machinery which it voluntarily incorporated within the collective agreement.

Another source of Board power to limit the union's right to strike during the term of the contract is found in the proviso to section $8(\mathrm{~d}),{ }^{22}$ making unilateral attempts to modify the existing terms and conditions of the collective bargaining contract an unfair labor practice. ${ }^{23}$ The impact of this proviso upon the right to strike depends in large part on the meaning given the concept of "modification" of the collective-bargaining contract. If a broad definition of "modification" is adopted, all conflicting interpretations of contractual clauses by management and the union might be considered an attempted modification by one of the parties ${ }^{24}$ since the contract presumably cannot embody both views, and could conceivably be interpreted by the Board or court to embody neither. This would give the Board responsibility along with courts and arbitrators for interpreting disputed provisions of collective agreements. A reading of the LMRA and the pertinent legislative history as a totality, however, lends little, if any, support to the Board's assumption of such a role.

22. Section $8(d)$, in relevant part:

Provided, That where there is in effect a collective-bargaining contract covering employees in an industry affecting commerce, the duty to bargain collectively shall also mean that no party to such contract shall terminate or modify such contract, unless the party desiring such termination or modification

(1) [serves written notice on other party]

(2) [offers to meet and confer with other]

(3) [notifies mediation and conciliation services]

(4) continues in full force and effect, without resorting to strike or lockout, all the terms and conditions of the existing contract for a period of sixty days after such notice is given or until the expiration date of such contract, whichever occurs later;

... the duties so imposed shall not be construed as requiring either party to discuss or agree to any modification of the terms and conditions contained in a contract for a fixed period, if such modification is to become effective before such terms and conditions can be reopened under the provisions of the contract. . .

LMRA § 8(d), 61 Stat. 142 (1947), 29 U.S.C. § 158(d) (1958).

This proviso conditions the duty to bargain imposed on management by $\S 8$ (a) 5,49 Stat. 452 (1935), as amended, 29 U.S.C. \$ 158 (a) 5 (1958) and on the union in $\S 8$ (b) 3, 61 Stat. 141 (1947), 29 U.S.C. $\S 158$ (b) 3 (1958).

23. Section 8 (d) prohibits all strikes to modify the collective agreement during its term except those occurring during bargaining pursuant to a reopening clause. NLRB v. Lion Oil Co., 352 U.S. 282 (1957) ; Local 3, United Packinghouse Workers v. NLRB, 210 F.2d 325 (8th Cir. 1954), cert. denied sub nom. Local 3, United Packinghouse Workers v. Wilson \& Co., 348 U.S. 822 (1954).

A strike in response to an employer unfair labor practice is not prohibited by $\S 8$ (d). Mastro Plastics Corp. v. NLRB, 350 U.S. 270, 287 (1956). See also notes 77-110 infra and accompanying text.

24. The majority opinion in United Steelworkers $v$. Warrior \& Gulf Nav. Co. supports the proposition that the contract represents a total settlement of the parties' rights. 363 U.S. 574 (1960). Cf. Jacobs Mfg. Co., 94 N.L.R.B. 1214 (1951), enforced sub nom. NLRB v. Jacobs Mfg. Co., 196 F.2d 680 (2d Cir. 1952). 
The narrow definition of "modification," apparently adopted by the NLRB, ${ }^{25}$ applies only to the most blatant attacks on the contract where little if any ambiguity or doubt exists as to the original intent of the parties, ${ }^{26}$ such as an attempt to change hours and wages expressly agreed upon in the collective agreement. ${ }^{27}$ It presumably excludes from the ambit of the section 8 (d) proviso all colorable arguments, claims and good faith disputes. Thus, the Board has assumed a very limited function as initial arbiter of disputes involving the meaning of a collective contract. ${ }^{28}$

The Board may assume a much more significant role in enforcing the agreement where the grievance procedure ends in arbitration and an award has been rendered. Whether interpretive of written contractual clauses or definitive of the parties' intent regarding the existence and continuation of established practices an arbitrator's award may be considered a settled term or condition of the contract. ${ }^{29}$ As such, the award governs the conduct of the parties as would any other specific provision of the bargain. Thus, except where the terms of the award itself are ambiguous, a strike to upset an arbitrator's award can hardly be said to involve a colorable dispute.

Although Board authority to treat a strike in repudiation of an arbitrator's award as a section 8 (d) violation is not legislatively prohibited, ${ }^{30}$ policy con-

25. See, e.g., United Tel. Co., 112 N.L.R.B. 779, 781 (1955) ; see also Morton Salt Co., 119 N.L.R.B. 1402 (1958); McDonnell Aircraft Corp., 109 N.L.R.B. 930, 934 (1954); International Union, UMW, 117 N.L.R.B. 1095, 1121 (1957) (trial examiner), affirmed without passing on this issue, $i d$. at 1095; cf. Consolidated Aircraft Corp., 47 N.L.R.B. 694, 706 (1943). See generally Note, 69 YALE L.J. 309 (1959).

It has been suggested that this approach by the Board accords with legislative policy. 69 Y ALE L.J. at 310.

26. The Board has attempted to ascertain what settled terms exist by examining the bargaining history and established practices of the parties. See The Borden Co., 110 N.L. R.B. 802, 805 (1954) ; Jacobs Mfg. Co., 94 N.L.R.B. 1214, 1227 (1951) (concurring opinion), cnforced sub nom. NLRB v. Jacobs Mfg. Co., 196 F.2d 680 (2d Cir. 1952); California Portland Cement Co., 101 N.L.R.B. 1436, 1437 (1952) ; Crown Zellerbach Corp., 95 N.L.R.B. 753 (1951); Bowman, An Employer's Unilateral Action-An Unfair Labor Practice, 9 VANd. L. Rev. 487, 514-17 (1956).

27. Cf. Allied Mills, Inc., 82 N.L.R.B. 854 (1949), construing the $\$ 8$ (d) exception to the duty to bargain imposed by $\S \S 8(\mathrm{a}) 5$ and $8(\mathrm{~b}) 3$ to refer to:

... terms and conditions which have been integrated and embodied into a writing. Conversely it does not have reference to matters relating to "wages, hours and other terms and conditions of employment," which have not been reduced to writing. As to the written terms of the contract either party may refuse to bargain further about them, under the limitations set forth in the paragraph ...

Id. at 862. Quoted with approval in Tide Water Associated Oil Co., 85 N.L.R.B. 1096, 1099 (1949) ; United Tel. Co., 112 N.L.R.B. 779, 789 (1955).

28. See cases cited note 25 stpra; see also Meltzer, The Supreme Court, Congress, and State Jutrisdiction Over Labor Relations: II, 59 CoLuM. L. REv. 269, 282 (1959).

29. Note, 69 Yare L.J. 309, 311 (1959). See also Wollett, The Duty to Bargain Over the "Unwrittcn" Terms and Conditions of Employnent, 36 Texas L. Rev. 863 (1958).

30. See Note, 69 Yale L.J. 309, 314-15 (1959); H.R. Rep. No. 510, 80th Cong., 1st Sess. 34-35 (1947) ; S. REP. No. 105, 80th Cong., 1st Sess. 24 (1947). 
siderations may suggest the desirability of restraint in this area. The argument has been made that the formulation of a consistent body of federal arbitration law may be unduly burdened by the application of section $8(d)$ to disputes involving arbitration awards. ${ }^{31}$ Should it embark on this course, the Board would face the same problems which courts have faced and about which they have disagreed-determining the arbitrability of the controversy, ${ }^{32}$ the validity of the arbitrator's award in the face of procedural defects, ${ }^{33}$ and the scope to be accorded the final arbitration decision. ${ }^{34}$ An independent line of authority ${ }^{35}$ at variance with the already conflicting court doctrines might in fact result. ${ }^{30}$

But a decision by the Board, on this ground, to limit the exercise of its power in this area would be unwarranted in light of decisions of the Supreme Court in the Steelworkers ${ }^{37}$ cases, defining the function of the arbitrator and scope of permissible court review of the validity of the award. ${ }^{38}$ It now seems clear that all doubts as to the arbitrability of a grievance are to be resolved in favor of arbitration and that the arbitrator is to be accorded the broadest possible discretion under the contract. ${ }^{39}$ While the Court in the Steelworkers cases was addressing itself to the judiciary, there is no apparent reason why the Board, when it is functioning as an interpretor of the contract, should not extend to the arbitrator the same deference now required of the courts. ${ }^{10}$ Problems of reviewability, particularly those involving procedural questions, ${ }^{41}$ may still remain open despite the Steelworkers decisions, but the path which federal arbitration law is to follow and the part it is to play in the resolution of contractual disputes have been clarified and Board decisions under section

31. Note, 69 Y YLE L.J. 309, 315 (1959).

32. Id. at 315 n. 39 and cases cited therein.

33. Id. at 316 n. 40 .

34. Id. at $316 \mathrm{n} .41$ and cases cited therein.

35. The Board is not bound to follow circuit court decisions and indeed has often indicated its intention not to do so. E.g., International Union, UMW, 117 N.L.R.B. 1095, 1120 (1957) ; Teamsters Union v. Curtis Bros., 119 N.L.R.B. 232, 245-46 (1957), enforcesment denied, 274 F.2d 55 (D.C. Cir. 1958), aff'd, 362 U.S. 274 (1960).

36. On the interrelation between arbitration decisions and the courts, prior to the Supreme Court's decisions in the Steelworkers cases, cited at note 1 supra, see generally Summers, Judicial Review of Labor Arbitration, or Alice Through the Looking Glass, 2 Buffalo L. Rev. 1 (1952); Cox, Current Problems in the Law of Grievance Arbitration, 30 Rocky Mr. L. REv. 247 (1958); Cox, Grievance Arbitration in the Federal Courts, 67 Harv. L. Rev. 591 (1954) ; Cox, Reflections Upon Labor Arbitration, 72 HaRv. L. Rev. 1482 (1959) ; Mendelsohn, Enforceability of Arbitration Agreements Under Taft-Hartley Section 301, 66 YALE L.J. 167 (1956); Wellington, Judge Magruder and the Labor Contract, 72 HARv. L. REv. 1268 (1959).

37. See note 1 supra.

38. See notes 124-48 infra and accompanying text.

39. For a discussion of the holdings in the Steelworkers cases, see notes 148-50 infra and accompanying text.

40. The Supreme Court has indicated that the NLRB is not to intrude into the substantive aspects of the collective agreement. NLRB v. Insurance Agents' Union, 361 U.S. 477,490 (1959).

41. See Note, 70 Yale L.J. 611 (1961). 
8 (d) should present no insurmountable problems of accommodation with court rulings. ${ }^{42}$

Thus, the possibility of occasional conflict with court decisions would not seem sufficiently serious to preclude Board enforcement of arbitration awards were there some strong policy favoring such enforcement, for example, its ability to provide an effective remedy unavailable in the courts. ${ }^{43}$ But the Board cannot award damages to an employer. Should the recovery of a money judgment be deemed a necessary element of an employer's relief, however, there would be no reason to deny him access to a court while he is invoking the procedure of the Board. ${ }^{45}$

Justification for the exercise of Board power in this area may lie in the availability of injunctive relief, which is often both the most effective weapon in dealing with strikes against arbitration awards and the only meaningful remedy available to the employer. ${ }^{46}$ Such relief may be obtained in actions brought before the Board at two stages and with varying effect. Upon issuance of an unfair labor practice complaint, the Board may seek a temporary restraining order from a federal district court ${ }^{47}$ upon the completion of its formal investigative and hearing processes, a cease and desist order may be issued. ${ }^{48}$ The status of similar relief in a court-initiated action is unclear. ${ }^{49}$ Should the Supreme Court hold that both federal and state courts are without

42. But cf. Note, 69 Y YLE L.J. 309, 315-20 (1959).

43. Cf. id. at 319 .

44. See United Constr. Workers v. Laburnum Constr. Corp., 347 U.S. 656, 665 (1954); Meltzer, The Supreme Court, Congress, and State Jurisdiction Over Labor Relations, 59 Coluar. L. Rev. 269, 283 (1959); Note, 69 Yale L.J. 309, 319 (1959). Cf. Local 60, International Bhd. of Carpenters v. NLRB, 81 Sup. Ct. 875 (1961), invalidating as punitive an NLRB order requiring a union to refund dues collected under an illegal closed-shop agreement.

45. Once an arbitration award has become a settled term of the contract, any attempt to modify or terminate the award would be a breach of contract in addition to an unfair labor practice. The fact that an unfair labor practice charge has been filed should not bar a court from considering the question of breach of contract and granting any relief, including damages, which it deems appropriate. See Note, 69 Y ALE L.J. 309, 317 (1959) and discussion at notes 116-18 infra and accompanying text. See generally Meltzer, The Supreme Court, Congress, and State Jurisdiction Over Labor Relations: II, 59 CoLuM. L. REv. 269 (1959).

46. See Cox, Current Problems in the Laze of Grievance Arbitration, 30 RockY Mr. L. REv. 247, 255 (1958).

47. LMRA $\S 10(j), 61$ Stat. 149 (1947), 29 U.S.C. $\$ 160$ (j) (1958). The Board has discretionary authority to seek a temporary restraining order under $\S 10(j) ; c f . \S 10(l)$ wherein the Board must seek a restraining order upon issuance of a complaint alleging violations of $\S \S 8(\mathrm{~b})(4)(\mathrm{A}),(\mathrm{B}) \mathrm{\&}(\mathrm{C})$.

48. LMRA $\S \S 10(\mathrm{~b}), 10$ (c), 61 Stat. 146-47 (1947), 29 U.S.C. $\S \S 160(\mathrm{~b}), 160$ (c) (1958). The efficacy of a cease and desist order depends in the final instance on court enforcement by injunction, LMRA § 10(e), 61 Stat. 147-48, 29 U.S.C. $\$ 160$ (e) (1958). Section $10(l)$ of the Act creates a specific exception to the rigorous requirements of $\S 4$ of the Norris-LaGuardia Act, 47 Stat. 70 (1932), 29 U.S.C. § 104 (1958) governing injunction by federal courts in labor disputes.

49. See Teamsters Union v. Yellow Transit Freight Lines, 282 F,2d 345 (10th Cir. 1960), cert. granted, 81 Sup. Ct. 378 (1961); see notes 206-48 infra and accompanying text. 
power to issue injunctions prohibiting a strike in breach of contract, ${ }^{50}$ it could reasonably be argued that the Board should entertain complaints charging breach of an arbitration award under section $8(\mathrm{~d})$, since it would be the only institution capable of affording adequate relief.

On the other hand, should the Supreme Court uphold the power of either the state or federal courts, or both, ${ }^{51}$ to issue injunctions in breach of a nostrike promise, there would seem to be no justification for the exercise of Board power in this area. The availability of temporary restraining orders from the Board is more illusory than real. Not only has the Board been extremely reluctant to request such orders in section $8(d)$ situations, but the courts have refused to issue such orders in a high proportion of those cases in which a request has been made. ${ }^{52}$ Cease and desist orders are more frequently granted but their value to an employer facing a strike is negligible since they are issued long after the commencement of the strike.53 Moreover, since the Board's injunctive remedies are not self-enforcing, further delay may be occasioned by the necessity of petitioning a court to enjoin noncomplying parties. ${ }^{54}$ Furthermore, utilization of the Board's expertise in this area would seem to be overshadowed by the disadvantage of adding still further to the Board's overcrowded docket. ${ }^{55}$ Therefore, since an expanded use of section 8 (d) would not contribute in most circumstances to industrial stability, the Board can best aid the contractual grievance-settling process by leaving the enforcement of arbitration awards to the courts.

\section{Contractual Restrictions on the Right to Strike}

\section{Source and Scope}

A recent study indicates that ninety-four percent of all collective agreements contain some explicit contractual limitation on the right of the union to strike during the term of the bargain. ${ }^{56}$ While the scope and language of these no-

50. See note 195 infra and accompanying text.

51. See notes 206-48 infra and accompanying text.

52. See Note, 69 YALE L.J. 309, 319 n.64 (1959). The number of $\S 10(j)$ injunctions sought in any one year from 1953 through 1958 never exceeded 7. Of 18 sought in this period, 10 were granted. Ibid. In 1959, all 4 requests for such relief were granted. 24 NLRB ANN. REP. 179 (1959).

53. The time consumed between the filing of a charge and final Board disposition of the matter averages 475 days. See Report of the Advisory Panel On Labor Management Relations Law to the Senate Comm. On Labor and Public Welfare, S. Doc. No. 81, 86th Cong., 2d Sess. at 1-2 (1960).

In 1953 the time was approximately one year. See Hearings Before the Senate Connmittee on Labor and Public Welfare on Proposed Revisions of the Labor Management Rclations Act of 1947, 83d Cong., 1st Sess., pt. 1, at 531 (1953). An additional period averaging 8.5 months is consumed should the Board order be appealed. $I d$. at 556.

54. The Board's orders are not self-enforcing. See notes 47-48 supra.

55. See note 53 supra.

56. This study, revised as of October 28,1960 , appears in 2 Collective Bargaining Negotiations and Contracts $\S 77: 1$ (1960) [hereinafter cited as 2 CBNC]. The $94 \%$ figure represents an increase of $5 \%$ since 1957. 
strike clauses vary greatly, they may be divided into two basic categories: "absolute and unconditional" and "conditional." 57 Forty-eight percent of collective contracts contain clauses of the former description, ${ }^{58}$ which prohibit all strikes during the term of the agreement, although the type of activity banned varies according to the definition of the term "strike" adopted by the parties. "Conditional" no-strike clauses, those which lift the ban only under certain circumstances, may be subdivided into two categories: those which exempt certain subjects from the prohibition on strikes, for instance, issues not arbitrable, and those which waive the no-strike provision upon the fulfillment of some procedure, for instance, exhaustion of the contract's grievance procedure. 69

In addition, most labor contracts contain elaborate provisions governing the settlement of disputes arising during the terms of the bargain.60 These provisions nearly always designate arbitration as the final step of the grievance machinery. ${ }^{61}$ Where such provisions are operative it is reasonable to presume in the absence of strong bargaining history to the contrary or some explicit contractual limitations on the right of the union to strike that the parties intended to substitute the contract's grievance procedure for the use of economic force in the resolution of arbitrable disputes. Thus, the weight of authority supports the view that in such a situation the union has implicitly bargained away its right to strike over arbitrable issues ;2 the contract is interpreted as

57. 2 CBNC $\$ 77: 1$.

58. 2 CBNC $\S \S 77: 1,77: 51,77: 101$. "These figures reflect an appreciable shift in favor of absolute bans since 1957; at that time 37 percent of contracts contained absolute bans, while 52 percent embodied conditional ones." 2 CBNC $\$ 77: 1$.

59. 2 CBNC $\$ \$ 77: 101-: 106$.

60. 2 CBNC $\$ 51: 1$, indicating that $99 \%$ of all collective bargaining contracts contain grievance procedures. See also Moore \& Nit, Arbitration Provisions in Collective Agreements, 1952, 76 MoNTH. LAB. Rev. 261, 263 (1953).

61. 2 CBNC $\$ 51: 7$. Ninety-four percent of contracts now provide for arbitration of grievances arising under the contract but not settled by the parties themselves.

62. United Const. Workers v. Haislip Baking Co., 223 F.2d 872, 876 (4th Cir. 1955), cert. denied, 350 U.S. 847 (1955) ; International Bhd. of Teamsters v. W.L. Mead, Inc., 230 F.2d 576, 583 (1st Cir. 1956), cert. dismissed per stipulation, 352 U.S. 802 (1956); Lewis v. Benedict Coal Co., 259 F.2d 346, 351 (6th Cir. 1958), modified, 361 U.S. 459 (1960) (i.e., equally divided Court sustained holding that union violated collective bargaining agreement; Justice Stewart, who had written the opinion for the Sixth Circuit finding an implied no-strike clause, did not sit); cf. Cox, The Duty to Bargain In Good Faith, 71 HARv. L. Rev. 1401, 1430 (1958); Wollet, The Duty to Bargain Over the "Unweritten" Terms and Conditions of Employment, 36 TEXAs L. Rev. 863, 875-76 (1958); Note, 66 YALE L.J. 284 (1956). See also NLRB v. Sands Mfg. Co., 306 U.S. 332 (1939) (establishing the right of an employer to discharge striking employees for violating provision of the collective agreement. The agreement did not appear to contain an express no-strike clause). NLRB v. Draper Corp., 145 F.2d 199, 204 (4th Cir. 1944).

But see International Union, UMW v. NLRB (Boore case), 257 F.2d 211 (D.C. Cir. 1958) (an explicit no strike clause contained in prior agreements had been deleted from the current contract); accord, Mile Branch Coal Co. v. UMW, 286 F.2d 822 (D.C. Cir. 1961) (Boone cited as controlling). 
though it contained an explicit no-strike clause coextensive with the arbitration clause.

This approach seems to be a natural concomitant of the doctrine enunciated by Justice Douglas in Steelworkers that arbitration is the quid pro quo of a no-strike clause. ${ }^{63}$ Indeed, it can be argued that a strike and arbitration are inherently incompatible. ${ }^{64}$ The strike is a weapon designed to put direct economic pressure on the employer and thus to weaken his incentive and ability to resist union demands; arbitration is a procedure designed to substitute the experience and judgment of an impartial third party for economic conflict resulting from the failure of direct negotiation between the parties primarily involved. ${ }^{65} \mathrm{~A}$ strike weakens the value of arbitration by putting pressure on the employer to modify the posture of his presentation or to settle the dispute outside of and without regard to the method agreed upon in the contract. ${ }^{60}$

But before a broad no-strike ban is implied, the bargaining history of the contract in question and the scope of any existing explicit no-strike clause should be examined and interrelated. When the contract contains a clause restricting specific strike activity, ${ }^{67}$ there would appear to be a strong presumption against implying any further strike limitation from the presence of the arbitration section. A finding that strike limitations are always coextensive with arbitration provisions would have the effect of making redundant a clause which restricts specific strike activity. If, on the one hand, a broad no-strike restriction is implied where no explicit clause is present and, on the other hand, an explicit conditional no-strike clause is narrowly interpreted as intended, the union may be subjected to fewer strike restrictions if it agrees to insert a very limited no-strike clause in the contract than if no such clause is included. Although this is not to suggest that it is always improper to imply a no-strike clause from the arbitration provision of the contract, it does caution against creating a legal rule which compels or strongly presumes such a result. A no-strike clause should be implied only upon a showing that to do so is consistent with the language and implications of all other sections of the col-

63. See note 2 supra.

64. See International Bhd. of Teamsters v. W.L. Mead, Inc., 230 F.2d 576 (1st Cir. 1956), cert. dismissed per stipulation, 352 U.S. 802 (1956); cf. Note, 66 YALE L.J. 284 (1956).

65. Cox, Current Problems in the Law of Grievance Arbitration, 30 Rockx Mr. L. REv. 247 (1958): "The typical arbitration clause is written in words which cover, without limitation, all disputes concerning the interpretation or application of a collective bargaining agreement. ..." Id. at 261.

66. Such a strike on the part of the union could be characterized as an attempt to modify a fixed term or condition of the contract and as such may be an unfair labor practice under $\$ 8(d)$. See notes 22-23 supra.

See also Note, 66 Y ALE L.J. 284, 287 (1956) (suggesting the theory that were the strike one to modify the terms of the contract, it should be held in breach of contract as a matter of law notwithstanding the rationale of a no-strike clause implied from arbitration); Local 174, Teamsters Unión v. Lucas Flour Co., 356 P.2d 1 (Wash. 1960), cert. granted, 81 Sup. Ct. 902 (1961).

67. See note 56 supra and accompanying text. 
lective agreement and if there is nothing in the relevant bargaining history of the parties which would belie such a conclusion. ${ }^{68}$

The presence of a no-strike ban and its scope, however, should not be determinative of the effect to be accorded a contractual arbitration agreement. Nevertheless, in United Mine Workers, ${ }^{69}$ upon findings that the parties had explicitly rescinded a no-strike clause and that a no-strike limitation could not be implied from the arbitration clause, the court held that the grievance and arbitration provision was, in effect, "a 'gentleman's agreement" and therefore not binding on the parties. ${ }^{70}$ Such a finding is not compelled as a matter of federal policy or law and, in many instances, may be contrary to the intent of the parties. ${ }^{71}$ The arbitration provision is not necessarily dependent upon a promise not to strike. The agreement to arbitrate could be specifically enforced under section $301^{72}$ with the full force of court sanctions prompting compliance; only the remedies for a strike over an arbitrable matter would be unavailable. ${ }^{73}$ And there may be sound reasons, grounded in economic considerations and bargaining strategy, for the parties to agree that disputes should be adjudicated through grievance and arbitration procedures without providing or intending that the union's right to strike over arbitrable grievances be limited. For example, the union may desire to avoid the possibility of a suit for breach of contract under section 301 based on a strike over an arbitrable issue because it feels that it may be held liable for unauthorized strikes, or simply because it does not want to assume such liability under any circumstances." Assuming sufficient union bargaining power to impose this demand on the employer, either directly or in exchange for some other concession, it would seem improper for some tribunal to hold that the arbitration clause is not binding in the absence of a strike limitation. Furthermore, the specific enforcement of an arbitration provision is not a meaningless gesture merely because the union can strike during the course of the grievance and arbitration process. An award in the employer's favor, for example, will insulate him from a subsequent damages action brought by the union regarding the original dispute. ${ }^{75}$ Of more importance is the fact that, once the arbitrator's

68. A union strong enough to resist a contractual invasion of its right to strike would perhaps best safeguard its interests by bargaining for and including a clause in the contract indicating that its right to strike is not to be restricted by any provision in the contract.

69. 257 F.2d 211 (D.C. Cir. 1958).

70. Id. at 218.

71. Cf. NLRB v. Insurance Agents' Union, 361 U.S. 477 (1960). The conclusion of the Insurance Agents case, that economic force and the duty to bargain are not incompatible, would appear to leave the door open to a finding by a tribunal construing a labor contract that the parties' intent was not to ban a strike over a grievance which they were nonetheless bound by the contract to submit to arbitration.

72. See Textile Workers Union v. Lincoln Mills, 353 U.S. 448, 451 (1957), and the Steelworkers cases at note 1 supra.

73. See notes 194-205 infra and accompanying text.

74. See International Union, UMW v. NLRB, 257 F.2d 211, 217 (D.C. Cir. 1958).

75. A court would be bound to accord the strongest possible weight to an arbitrator's award. See Steclworkers cases at note 1 supra and accompanying text. 
decision is handed down, his interpretation is determinative of the meaning of the contract, and the Board may well hold continued union strike activity actionable under section 8 (d) as an attempt to "terminate" or "modify" the contract whether a no-strike clause exists or not. ${ }^{76}$

The problem of the scope to be accorded contractual strike limitations, whether they be explicit or implicit, assumes another dimension when a strike is directed against employer conduct which is ostensibly an unfair labor practice. It has been argued that the Supreme Court's decision in Mastro Plastics Corp. v. NLRB ${ }^{77}$ means that an exception should be read into any no-strike promise which would permit strikes against employer unfair labor practices. ${ }^{78}$ Mastro arose in the context of a proceeding bought by the union before the NLRB charging the employer with the discriminatory discharge of striking employees. The employer asserted as an affirmative defense that the contract's broadly cast no-strike clause ${ }^{79}$ was breached, that this breach deprived the striking individuals of their status as "employees" and hence their protection under Taft-Hartley ${ }^{80}$ In rejecting this defense, the Court took note of the fact that the strike was precipitated by a discharge which the NLRB had previously found to be an illegal interference with the employee's free choice of a statutory bargaining representative and held that the broad no-strike clause involved in this case should not be interpreted to prohibit such a strike. ${ }^{81}$ Therefore, the strike was not in breach of contract, the striking workers had not lost the protection of the Act and, in discharging them, the employer was guilty of an unfair labor practice. ${ }^{82}$

The impact of Mastro on actions arising under section 8 of Taft-Hartley is clear; if extended to actions brought in the courts under section 301, how-

76. The award would become a settled term of the contract. Note, 69 YALE L.J. 309, 311 (1959); see note 26 supra.

77. 350 U.S. 270 (1956).

78. Note, 66 Yale L.J. 284, 287-92 (1956) ; cf. Meltzer, The Supreme Court, Congress, and State Jucrisdiction Over Labor Relations: II, 59 ColuM. L. Rev. 269, 239-91 (1959).

It is not entirely clear from the Court's decision whether an express waiver of the right to strike against an unfair labor practice would have been sanctioned.

Section 502 of the LMRA would seem to provide a statutory exception to the Mastro doctrine on breach of a contractual no-strike clause. This section provides that work stoppages in response to a good faith belief that abnormally dangerous working conditions exist shall not be deemed a strike. Employees engaged in such stoppages are in a protected status and their discharge is an unfair labor practice. See Knight Morley Corp., 116 N.L.R.B. $140,145-47$ (1956).

79. 350 U.S. at 281 :

The Union agrees that during the term of this agreement, there shall be no interference of any kind with the operations of the Employers, or any interruptions or slackening of production of work by any of its members. The Union further agrees to refrain from engaging in any strike or work stoppage during the term of this agreement.

80. Id. at 277.

81. Id. at 278-79.

82. Id. at $271-72,278$. 
ever, serious problems of accommodation may arise. It may be a slight jump, but a jump nonetheless, to say that because an employer can not use a broad no-strike clause as a defense before the Board to the discharge of unfair labor practice strikers he automatically loses an affirmative right to sue for breach of contract in a court. If the Mastro case is read to sanction such a jump, a union charged with violation of a no-strike promise might be tempted to raise the defense that its strike action was in response to an employer unfair labor practice even under the most questionable circumstances, hoping to be relieved of liability under the Mastro doctrine should its defense be upheld and, in any event, to delay final adjudication of the breach of contract suit while the merit of the defense is tested. ${ }^{83}$

A tribunal faced with an unfair labor practice defense to a breach of contract action could proceed to adjudicate the merits of the defense, ${ }^{84}$ or it could stay the contract action pending disposition of an unfair labor practice charge filed with the NLRB. ${ }^{85}$ The efficacy of this second alternative depends upon the nature of the relief available in the forum selected to adjudicate the breach of contract suit. If the tribunal is unable to grant the employer injunctive relief against the strike, ${ }^{86}$ but limits him solely to recovery of damages, the delay might not be of consequence. On the other hand, if the tribunal can grant an injunction, a stay might effectively nullify the value of such relief to the employer. Board action, including the filing of the charge, preliminary investigation, the issuance of a complaint, and a final determination on the merits, generally consumes at least one year exclusive of appellate review. ${ }^{87}$

If after preliminary investigation, the Regional Director refuses to issue a complaint the time factor is less critical. ${ }^{88}$ More serious problems arise, however, if this refusal is not accompanied by some statement regarding the merits of the union's charge. ${ }^{89}$ An assumption that the refusal was based upon a find-

83. See Meltzer, The Supreme Cont, Congress, and State Jurisdiction Over Labor Relations: II, 59 CoLUM. L. REv. 269, 290-92 (1959) ; Note, 66 Y YLE L.J. 284, 291 n.40 (1956). Cf. Ezrine, Nadir of the No-Strike Clause, 8 LAB. L.J. 769, 804-05 (1957).

84. See Meltzer, supra note 83.

85. See Note, 66 Y ALE L.J. 284, $291 \mathrm{nn} .40-41$ (1956).

86. See notes 206-48 infra and accompanying text.

87. Board procedure is outlined in detail in 29 C.F.R. $\S 102$ (Supp. 1960). See also LMRA \& 109 (b) (c).

88. 29 C.F.R. $\S \S 101.5-.6$ (Supp. 1961). See also 29 C.F.R. $\S 102.15$ (Supp. 1961). After the filing of an unfair labor practice charge and answer by the respondent, a member of the Regional Director's field staff conducts an informal investigation. 29 C.F.R. $§ 101.4$ (Supp. 1961). If this investigation reveals no violation or insufficient evidence to substantiate the charge, the Regional Director can refuse to issue a complaint. 29 C.F.R. $\S \S$ 101.5-.6 (Supp. 1961). This decision is appealable to the General Counsel, whose determination is final. 29 C.F.R. $\S \S 101.6,102.19$ (Supp. 1961).

89. The refusal to issue a complaint may be based on substantive grounds, or on procedural grounds without reaching the substantive question. See 29 C.F.R. $\$ \S 101.5,101.6$, 102.19 (Supp. 1961). The Court in Garmon recognized that a refusal to exercise jurisdiction may be based on other than substantive grounds. 359 U.S. 236, 245-46 (1959). See also Note, 70 Y ALE L.J. 441, 451 (1961). 
ing of lack of merit may be unwarranted. Furthermore, a decision to proceed to the merits of the defense would conflict with the court's original intent to leave the issue to the Board and, in addition, may run afoul of the preemptionprimary jurisdiction doctrine, ${ }^{90}$ that is, the vesting by Congress of exclusive power in an administrative agency, the NLRB, to determine whether any given conduct constitutes an unfair labor practice and, upon an affirmative determination, the exclusive power to invoke sanctions against such conduct. ${ }^{01}$ This dilemma might be resolved if the tribunal deciding the contract claim seeks some further guidance from the Board as to the probable merits of the unfair labor practice defense, perhaps in the form of an advisory opinion. Although such a procedure has been suggested in a somewhat different context, ${ }^{92}$ it is not an available alternative under present Board practice and presents administrative and legal problems which make its adoption extremely doubtful.

The court may have no alternative but to defer to the Board despite these considerations since the right to adjudicate the merits of the defense itself seems preempted. ${ }^{93}$ But this doctrine should not be allowed to emasculate the effectiveness of breach of contract suits, for the jurisdiction of these suits is expressly vested by statute in forums other than the Board. ${ }^{94}$ Indeed, proposals to make breach of contract an unfair labor practice were specifically rejected by Congress, presumably to avoid conflict with judicial remedies.95

It would therefore seem that the tribunal adjudicating this contract action need not refrain from passing judgment on conduct which may be classified as an unfair labor practice by the NLRB. ${ }^{96}$ The role of the contract action tribunal involves an interpretation of the collective bargain; it should make no difference whether conduct which must be considered in order to make a meaningful determination of this action may also be an unfair labor practice. ${ }^{97}$ Once it has found a no-strike clause which ostensibly prohibits the union's conduct, the question before the court should be: Did the particular employer

90. San Diego Bldg. Trades Council v. Garmon, 359 U.S. 236, 244-45 (1959); Garner v. Teamsters Union, 346 U.S. 485 (1953); Weber v. Anheuser-Busch, Inc., 348 U.S. 468, 479 (1955) ; cf. Meltzer, The Supreme Court, Congress, and State Jurisdiction Over Labor Relations: II, 59 Colum. L. Rev. 269, 290 (1959); Note, 66 Y YLE L.J. 284, 291 n.40 (1956).

91. Garmon appears to hold that the roots of the preemptive doctrine lie in the notion of primary jurisdiction. 359 U.S. at 242. See Schwartz, The Pemumbra of State Regulation of Unfair Labor Practices, 38 B.U.L. REv. 553 (1958) ; Wellington, Labor and the Fcderal System, 26 U. Crr. L. Rev. 542, 556-61 (1959).

92. See Note, 70 YaLE L.J. 441, 448-52 (1961).

93. See notes $90-91$ supra.

94. Meltzer, supra note 90 , at $290-91$. The general intent of Congress in enacting $\$ 301$ was to strengthen the enforceability of the collective agreement. See 1 LEG. HIST. 292, 326.

95. See 1 Leg. Hist. 545-46, 556. Cf. Note, 69 Yale L.J. 309, 318 (1959).

96. Meltzer, supra note 90 , at 291 .

97. Cf. LMRA $\S 303$, providing for private damage suits arising as a result of a secondary boycott. 
conduct in question, analyzed in the light of what is known about the intent of the parties, the language of the no-strike provision, and the function of the collective agreement, excuse this particular strike ?98

The preemption doctrine has been raised and found inapplicable in breach of contract suits where the defendant's conduct, generally that of the union, might also have constituted an unfair labor practice. ${ }^{99}$ Hence, it is possible to have complaints regarding the same union conduct adjudged in mutually exclusive actions before different tribunals. For example, consider the situation posed by a one year contract with no provision for a wage reopener until the agreement's natural termination and with an apparently unqualified no-strike clause. After six months the union raises the question of a wage increase, is rebuked by the employer, and calls a strike. It would seem that the union has attempted to modify or terminate the contract in violation of sections 8 (b) (3) and $8(\mathrm{~d})$ of Taft-Hartley ${ }^{100}$ and has also breached the no-strike clause. The duplication of actions and of remedies inherent in this situation is in no way anomalous. The finding of a breach of contract and an unfair labor practice represent two distinct determinations which may or may not arise from the same conduct and which are entrusted by Congress to different tribunals. ${ }^{101}$ This same analysis should also apply to the situation where the union asserts an unfair labor practice by the employer in defense of a suit charging breach of a no-strike clause.

98. See Meltzer, supra note 90 , at 290.

99. E.g., Lodge 12, IAM v. Cameron Iron Works, 257 F.2d 467 (5th Cir. 1958), cert. denied, 358 U.S. 880 (1958); Independent Petroleum Workers v. Esso Standard Oil Co., 235 F.2d 401 (3d Cir. 1956); Textile Workers Union v. Arista Mills Co., 193 F.2d 529, 534 (4th Cir. 1951). Cf. Cox, The Duty to Bargain in Good Faith, 71 Harv. L. REv. 1401, 1438 (1958); Dunau, Contractual Prohibition of Unfair Labor Practices: Iutrisdictional Problemns, 57 Coruar. L. Rev. 52, 81 (1957) ; Note, 13 Vand. L. Rev. 804 (1960). But see Local 774, IAM v. Cessna Aircraft Co., 185 Kan. 183, 341 P.2d 989 (1959). Other courts, while not rejecting the preemption doctrine altogether, have attempted to circumvent its implications by holding that the contractual issues presented were not the same as unfair labor practice considerations. UEW v. Worthington Corp., 236 F.2d 364, 370 (1st Cir. 1956); Grunwald-Marx, Inc. v. Joint Bd. of Clothing Workers, 52 Cal. 2d 568, 343 P.2d 23 (1959). Cf. McCarroll v. Council of Carpenters, 49 Cal. 2d 45, 315 P.2d 322 (1957), cert. dertied, 355 U.S. 932 (1958); Note, 69 HARv. L. Rev. 725 (1956).

100. See note 22 supra.

101. These determinations should be viewed as distinct if only to avoid reducing the effectiveness of breach of contract actions, as a means of enforcing the collective agreement.

Certainly, if an otherwise arbitrable controversy happens also to be an unfair labor practice, the parties should not be forced to abandon their contract rights and be relegated "to the slow and creaking procedure which, like a wounded snake, has dragged its slow length along. ..." ... It is better to call the spade and say that enforcement of a contract to arbitrate grievances is different from an adjudication of an unfair labor practice by the National Labor Relations Board. This will prevent the nebulous determination of what part is contract and what part is unfair labor practice when the one part constitutes both.

Lodge 12, IAM v. Cameron Iron Works, 257 F,2d 467, 474 (5th Cir. 1958). 
When the Mastro case is viewed in its particular context, ${ }^{102}$ the refusal of the Court to find that the union bargained away its protection under section 7 despite the existence of an unqualified no-strike clause seems entirely proper. ${ }^{103}$ When the focus shifts to whether the employer can seek enforcement of the contract against the union, however, the Mastro case is no longer specifically in point. Just as it is improper to allow general contract language to weaken or destroy the effectiveness of the statutory protection afforded the parties through a Board proceeding, it seems equally improper to weaken or destroy the effectiveness of the no-strike provision of a collective agreement by reading into it an all-encompassing exception based on unfair labor practice considerations. Moreover, the heart of the Court's concern in Mastro may not have been the unfair labor practice as such but the preservation of the sanctity of the collective relationship. Both the Court and the Board reasoned that the parties should not be assumed to have bargained away the right to use selfhelp in response to activity which tended to destroy the relationship underlying the collective agreement. ${ }^{104}$ The employer's interference with the selection of the employee's statutory bargaining representative threatened the union's very existence. ${ }^{105}$ In facing a crisis of this nature the union should be free to use all of its traditional economic weapons as well as the sanctions of the NLRB. To limit the union to the time-consuming and laborious processes of the Board under such circumstances may be to destroy it. ${ }^{106}$ Not all unfair labor practices, however, need have effected the union in the same way nor have evoked the same concern from the court. The failure to promote an employee because he happens also to be a union steward from one job classification to another, for example, may create no such emergency. ${ }^{107} \mathrm{~A}$ statutory violation of this sort may be rectified satisfactorily through arbitration or could await decision

102. 350 U.S. at $279-84$.

The result in Mastro is grounded in part on the preferred position accorded to employees discharged for engaging in a strike protesting an unfair labor practice. See LMRA 2(3). This section has been previously interpreted to require reinstatement with back pay of employees striking over an unfair labor practice, even if replacements have been hired. NLRB v. Remington Rand, Inc., 130 F.2d 919, 927-28 (2d Cir. 1942). An employer need not, however, discharge replacements in order to rehire displaced employees engaged in an economic strike. NLRB v. Mackay Radio \& Tel. Co., 304 U.S. 333, 345-47 (1938). See also the Court's decision on the second question presented in Mastro, to the effect that $\S 8$ (d) is inapplicable to an unfair labor practice strike. 350 U.S. at 284-89. Cf. S, REP. No. 105, 80th Cong., 1st Sess. 24 ; H.R. Rep. No. 510, 80th Cong., 1st Sess. 34-35.

103. But see Ezrine, Nadir of the No-Strike Clanse, 8 LAB. L.J. 769, 803 (1957).

104. 350 U.S. at 281 .

105. 350 U.S. at 280 : "On the premise of fair representation, collective-bargaining contracts frequently have included certain waivers of the employees' right to strike and of the employer's right to lockout to enforce their respective economic demands during the term of those contracts. Provided the selection of the bargaining representative remains free, such waivers contribute to the normal flow of commerce and to the maintenance of regular production schedules." See also Ezrine, supra note 103, at 796.

106. See note 53 supra.

107. Cf. Ezrine, supra note 103, at 796. 
by the Board without seriously jeopardizing the position of the bargaining representative. ${ }^{108}$

The language of the opinion in Mastro lends support to this interpretation. The Court rejected the employer's broad interpretation of the no-strike clause because it would "necessarily include all strikes, even those against unlawful practices destructive of the foundation on which collective bargaining must rest"109 and "would eliminate for the whole year, the employees' right to strike, even if petitioners, by coercion, ousted the employees' lawful bargaining representative and, by threats of discharge, caused the employees to sign membership cards in a new union." 110 The Court was refusing to read into the contract a surrender of the strike weapon where employer conduct made such a weapon crucial to the continued life of the union. It was laying down a policy which need not necessarily hinge on the phrase "unfair labor practice," a policy which can be applied to actions on the labor contract without destroying the usefulness of a suit for breach of the no-strike promise.

This view of Mastro seems to have been adopted by the NLRB in Mid-zest Metallic Products, Inc. ${ }^{111}$ where the union had agreed to a no-strike clause waiving its right to strike until the contractual grievance procedure was exhausted. The union initiated an unfair labor practice proceeding against the employer based on the firing of employees who had struck in protest over the discriminatory discharge of a fellow worker. Conceding that the strike had been initiated in response to an unfair labor practice the Board, nonetheless, held it to be unprotected activity. ${ }^{112}$ Mastro was distinguished on the grounds that a contrary holding in that case would have required a waiver of the right to strike against an unfair labor practice during the entire term of the agreement. ${ }^{113}$ In Mid-zest Metallic, however, the union only limited its right to strike until the contractual grievance procedure including arbitration by consent of the parties had been exhausted, a period of about five days. The Board distinguished the case from Mastro on the grounds that in Mid-zvest Metallic the union was not "jeopardizing its very existence by removing self-help

108. Grievances are often arbitrated despite the fact that they may also involve unfair labor practices. See Lodge 12, IAM v. Cameron Iron Works, 257 F.2d 467 (5th Cir. 1958), cert. denied, 358 U.S. 880 (1958). Though the NLRB has recognized that it is not bound by the arbitrator's award, e.g., Monsanto Chem. Co., 97 N.L.R.B. 517 (1951), enforced, 205 F.2d 763 (8th Cir. 1953) ; NLRB v. Walt Disney Prods., 146 F.2d 44 (9th Cir. 1945), cert. devied, 324 U.S. 877 (1945), it generally defers to it, cf. Local 9735, UMW v. NLRB, 258 F.2d 146 (D.C. Cir. 1958). See generally Note, 69 HARv. L. Rev. 725 (1956); Sanoff \& Summers, Effects of Collective Bargaining Provisions on NLRB Actions, 8 LAB. L.J. 676 (1957); Wollett, The Interpretation of Collective Bargaining Agreements: Who Should Have Primary Jurisdiction, 10 LAB. L.J. 477 (1959); Note, 13 VAND. L. REv. 804 (1960).

109. 350 U.S. at 281 .

110. Id. at 283 .

111. 121 N.L.R.B. 1317 (1958); cf. Meltzer, supra note 90, at 290 n.267.

112. 121 N.L.R.B. 1317 (1958).

113. Id. at $1319-20$. 
against unfair labor practices for a substantial period of time."114 Mastro was limited to its facts-a ban on unfair labor practice strikes was not to be implied from a general no-strike clause when to do so would have a substantial adverse effect on the position of the union as an effective bargaining representative.

So limited, the policy basis of Mastro applies to all tribunals determining the scope of a contractual no-strike clause. Mastro itself could well have been a contract action had the employer sought relief from the union's strike through a suit on the contract rather than through the discharge of employees who were engaged in allegedly unprotected activity. The union then would have raised employer unfair labor practices as an affirmative defense. If the no-strike clause is found inapplicable in one situation, it is hard to reason that it should be controlling in the other, for the union's right to retaliate with economic force when its life is threatened should not depend on the employer's subsequent choice of remedies. Thus a tribunal adjudicating the question of the breach of the no-strike promise should not involve itself in unfair labor practice considerations. Instead, it should consider itself bound by the Mastro mandate that absent a clear manifestation of intent to the contrary the union did not bargain away its right to strike against activity which threatened the relationship underlying the agreement and the union's continued existence. ${ }^{115}$

\section{Adjudicating Forum}

Where no provision is made for the initial arbitration of claims arising under the collective bargaining agreement, either a federal or state court would appear competent to adjudicate a claim alleging union action in violation of a contractual no-strike clause. ${ }^{116}$ The choice between these forums would depend upon considerations of convenience and the availability of adequate remedies. ${ }^{117}$ If, in the usual case, ${ }^{118}$ the parties have expressly agreed to submit disputes to arbitration, the competency of the court may be challenged on the ground

114. Id. at 1320 .

115. See notes 78-81 supra and accompanying text.

116. See McCarroll v. Los Angeles County Dist. Council of Carpenters, 49 Cal. $2 \mathrm{~d}$ 45, 315 P.2d 322 (1957), cert. denied, 355 U.S. 432 (1958) (the court having found the arbitration clause inapplicable); Wellington, Labor and The Federal System, 26 U. CHI. L. Rev. 542, 557-58 (1959); Comment; 70 Yale L.J. 70, 100 (1960); cf. W.L. Mead, Inc. v. International Bhd. of Teamsters, 230 F.2d 576 (1st Cir. 1956), cert. devied, 352 U.S. 302 (1956).

Despite the persuasive reasoning of Justice Traynor in the McCarroll case that state courts have concurrent jurisdiction to apply federal substantive law to breach of contracts actions under LMRA \& 301, the issue is not yet settled. See Charles Dowd Box Co., Inc. v. Courtney, 169 N.E.2d 885 (1960), cert. granted, 81 Sup. Ct. 699 (1961); Local 174, Teamsters Union v. Lucas Flour Co., 356 P.2d 1 (1960), cert. granted, 81 Sup. Ct. 902 (1961).

117. See notes 206-48 infra and accompanying text.

118. Ninety-four percent of all collective agreements contain provisions for the arbitration of disputes arising under the contract and not resolved by the parties themselves. 2 CBNC \& $51: 7$. 
that the asserted breach of a no-strike clause is a proper subject for arbitration. ${ }^{119}$ Facing similar challenges to their competency in the past, courts have often become embroiled in problems relating to the scope and application of the Federal Arbitration Act, ${ }^{120}$ whether the union's conduct could constitute a grievance, ${ }^{121}$ whether arbitration was available at any time or only at the culmination of the grievance procedure, ${ }^{122}$ or whether the words "differences" or "disputes" were used in the agreement. ${ }^{123}$

New light has been shed upon the problems of accommodating courts and arbitrators, however, by Justice Douglas in United Steelworkers v. Warrior \& Gulf Navigation Co., ${ }^{124}$ a case involving the arbitrability of a dispute over the right of the employer to contract out maintenance work. The union claimed that the dispute, which it characterized as a partial lockout, violated the collective agreement and was covered by the agreement's broad arbitration clause. ${ }^{125}$ The employer maintained that contracting out fell within the "func-

119. See, e.g., McCarroll v. Los Angeles County Dist. Council of Carpenters, $49 \mathrm{Cal}$. $2 d$ 215, 315 P.2d 322 (1957), cert. denied, 355 U.S. 932 (1958); Compare Signal Stat. Corp. v. Local 475, UEW, 235 F.2d 298 (2d Cir. 1956), cert. denied, 354 U.S. 911 (1956), rehearing denied, 355 U.S. 852, with Murkel Elec. Prods. v. UEW, 202 F.2d 435 (2d Cir. 1952) and Drake Bakeries v. Local 50, American Bakery Workers, 287 F.2d 155 (2d Cir. 1961). See generally Fulda, The No Strike Clause, 21 Geo. WASE. L. Rev. 127, 157-70 (1952) ; see also Ezrine, supra note 103, at 782-90.

120. 9 U.S.C. \$\$ 1-14 (1958). Compare Lewittes \& Sons v. United Furniture Workers, 95 F. Supp. 851 (S.D.N.Y. 1951), with International Union United Furniture Workers v. Colonial Hardwood Flooring Co., 168 F.2d 33 (4th Cir. 1948). See also cases and authorities collected in Note, 69 Yal. L.J. 309, 316 n.44 (1959).

121. E.g., Hoover Motor Express Co. v. Local 327, Teamsters Union, 217 F.2d 49 (6th Cir. 1954).

122. E.g., Harris Hub Bed \& Spring Co. v. UEW, 121 F. Supp. 40 (W.D. Penn. 1954).

123. Compare UAW v. Benton Harbor Indus., 242 F.2d 536 (6th Cir. 1957), cert. denied, 355 U.S. 814 (1957), with Tenny Eng'r, Inc. v. UEW, 174 F. Supp. 878 (D.N.J. 1959).

124. 363 U.S. 574 (1960).

125. Id. at 576-77.

The grievance procedure provided: Issues which conflict with any Federal statute in its application as established by Court procedure or matters which are strictly a function of management shall not be subject to arbitration under this section.

Should differences arise between the Company and the Union or its members employed by the Company as to the meaning and application of the provisions of this agreement, or should any local trouble of any kind arise, there shall be no suspension of work on account of such differences but an earnest effort shall be made to settle such differences immediately in the following manner:

A. For Maintenance Employees: First, between the aggrieved employees, and the Foreman involved; Second, between a member of members of the Grievance Committee designated by the Union, and the Foreman and Master Mechanic.

‥

Fifth, if agreement has not been reached the matter shall be referred to an impartial umpire for decision. The parties shall meet to decide on an umpire acceptable to both. If no agreement on selection of an umpire is reached, the parties shall jointly petition the United States Conciliation Service for suggestion of a list of umpires from which selection will be made. The decision of the umpire shall be final. 
tion of management" exception to the arbitration provision. ${ }^{126}$ In ordering arbitration of the dispute, the Court acknowledged that arbitration is a matter of contract and that a party cannot be required to submit a dispute to arbitration unless he has agreed to do so, but stated that a court should "view with suspicion"127 an attempt to entangle it in the construction of a substantive provision of a labor agreement when the alternative is utilization of an arbitrator:

An order to arbitrate the particular grievance should not be denied unless it may be said with positive assurance that the arbitration clause is not susceptible to an interpretation that covers the asserted dispute. Doubts should be resolved in favor of coverage. ${ }^{128}$

Since a no-strike clause is a substantive provision of a collective agreement, absent the most "forceful evidence" 129 of an intent to exclude the claim from arbitration required by Warrior $\&$ Gulf, it certainly could be argued that a determination of the existence, scope and breach of a strike ban is properly a function of an arbitrator acting under a contractual arbitration provision.

One can develop a persuasive argument based upon the factual context of Warrior \& Gulf and the practicalities of the arbitrator's position, however, that the court and not the arbitrator is the proper institution for resolving conflicts involving a contractual strike ban. The Court specifically noted in Warrior \& Gulf that the dispute in question, the dismissal of nineteen employees, ${ }^{130}$ necessitated in part by the contracting out of work, was peculiarly suited to arbitration. "Contracting out work is the basis of many grievances; and that type of claim is grist in the mills of the arbitrators." 131 Disputes involving no-strike clauses do not seem to fit within the category of claims traditionally submitted to arbitration, ${ }^{132}$ and may therefore fall outside the ambit of Warrior \& Gulf. This does not foreclose arbitration of such disputes. ${ }^{133}$ It merely nullifies the presumption of arbitrability which would

126. Id. at 577.

127. Id. at 585.

128. Id. at 577.

129. Id. at 505 .

130. As a result of layoffs, the bargaining unit was reduced from 42 to 23 employees. Id. at 574 .

131. Id. at 574. See generally Shulman, Reason, Contract, and Law in Labor Relations, 68 HaRv. L. REv. 999 (1955).

132. Shulman, supra note 131 , at 1007-08. See also 2 CBNC $\$ 51: 261-68$. But cf. Gregory, The Law of the Collective Agreement, 57 MICH. L. Rev. 635, 644-46 (1959); Fulda, supra note 119, at 172 .

133. The parties could specifically provide that the question of the breach of the nostrike clause is for the arbitrator.

In the event of a substantial violation of this clause [no-strike clause], on the part of the Union, the Association shall have the option to terminate this agreement. The existence or non-existence of such substantial violation shall be determined by the Impartial Chairman on all the Facts and Circumstances.

Paragraph 51, Collective Agreement, United Popular Dress Mfgr. Ass'n with I.L.G.W.U. \& Dress Makers' Joint Council, appearing in Minkoff v. Scranton Frocks, Inc., 45 I.R.R.M. 2789, 2791 (S.D.N.Y. 1960). 
otherwise arise and rests the determination on such crucial considerations as the intent of the parties and their previous bargaining history. ${ }^{134}$

Evidence of the parties' intent to by-pass the arbitrator in the resolution of breach of no-strike clause disputes may be found in the nature of the contractual grievance procedure and the relationship of the arbitration provision to this procedure. Often grievances must be negotiated initially by the immediately aggrieved individual or a union steward and the foreman or other low-ranking management representative. ${ }^{135}$ Failure to resolve the dispute at this level, then, is a prerequisite to arbitration. ${ }^{136}$ Thus it may be argued that the parties intended to arbitrate only those questions which would be appropriate for initial negotiation and settlement by a foreman and shop steward. ${ }^{137}$ Since it is doubtful whether a question of the breach of a no-strike clause is an appropriate subject of discussion at this level, it would seem to follow that it was not intended to be arbitrable.

It may also be argued that the future effectiveness of the arbitrator is jeopardized when he deals with problems of such consequence to the parties as breach of a no-strike clause. The arbitrator is usually selected by the parties themselves, often on an ad hoc basis, ${ }^{138}$ and his effectiveness is directly related to the confidence which they place in his integrity and judgment. ${ }^{139}$ This confidence is rarely undermined when the decision involves matters of a relatively routine and noncrucial nature in the overall scheme of industrial relations, such as promotion or discharge of a single worker. ${ }^{140}$ But when the decision is of utmost importance to parties who are deeply committed to their position, it will be extremely difficult for an arbitrator to maintain an air of impartiality in selecting between conflicting testimony and to avoid appearing biased in the eyes of the party against which the decision is rendered.141

While it may be true that the difficulty of the arbitrator's function varies directly with the increasing importance of his decision to the parties, his role

134. The question is whether the collective bargaining agreement requires arbitration to determine if defendant's conduct violates the no-strike clause, or whether the court itself may make this determination as with all problems of contract interpretation, the answer must reflect the contention of the parties.

McCarroll v. Los Angeles County Dist. Council of Carpenters, 49 Cal. 2d 45, 315 P.2d 322 (1957), cert. denied, 355 U.S. 932 (1958). See also Drake Bakeries v. Bakery Workers, 47 L.R.R.M. 2612, 2614 (2d Cir. 1961) ; Cox, Reflections Upon Labor Arbitration, 72 HARv. L. REv. 1482, 1503-04 (1959).

135. 2 CBNC $\$ \S 51: 1,51: 21,51: 61$.

136. 2 CBNC $\$ 51: 281$; Shulman, supra note 131 , at 1007-08.

137. See, e.g., Drake Bakeries v. Bakery Workers, 47 L.R.R.M. 2612 (2d Cir. 1961); McCarroll v. Los Angeles County Dist. Council of Carpenters, 49 Cal. 2d 45, 315 P.2d 322 (1957), cert. denied, 355 U.S. 932 (1958).

138. See 2 CBNC $\$ 51: 7$, indicating that 77 percent of collective bargaining contracts provide for selection of an arbitrator on a case-by-case basis.

139. See Shulman, sutpra note 131.

140. Cf. id. at 1007-10.

141. Id. at 1012, 1019-21. 
as a keystone of industrial stability may also be jeopardized if he is reduced to dealing only with routine or minor disputes. ${ }^{142}$ Arguably, the more serious the dispute, the more reason that the contract itself assure its settlement. It is also more likely that an awareness of the nature of the industry, the overall problems of the parties, and their bargaining history will be crucial to a just and adequate resolution of the dispute. ${ }^{143}$ It is in this role that the arbitrator's background and expertise can be of greatest benefit. In fact, the arbitrator has fulfilled such a function in disputes which may be of equal or greater importance to the parties than the question of the breach of a no-strike clause. ${ }^{144}$ Indeed, a contrary resolution of the dispute which Justice Douglas envisioned in Warrior \& Gulf as presumptively within the scope of arbitration could have resulted in the reduction of the size of the union's bargaining unit by nearly one-half, certainly a decision of crucial importance to the union. ${ }^{145}$

Furthermore, in view of the facts of the Warrior \& Gulf case, it is doubtful whether courts should give much weight to the point in time at which arbitration occurs within the contractual grievance procedure. Justice Douglas found that the dispute in issue-the discharge of employees necessitated by the contracting out of work they had previously performed-was particularly suited to arbitration. ${ }^{146}$ The collective agreement provision applicable to the dispute established a five step grievance procedure beginning with direct negotiation between the "aggrieved employees" and the foreman and culminating in arbitration. ${ }^{147}$ It is difficult to imagine a grievance procedure which begins at a more basic level or a dispute less susceptible of resolution by aggrieved employees and their foreman. Thus, for courts to infer from the limited efficacy of initial grievance proceedings an intent of the parties to exclude certain issues from arbitration seems out of harmony with the facts and the philosophy of Warrior $\mathcal{E}$ Gulf and intrudes into areas of contractual intent more properly left to the expertise of the arbitrator. ${ }^{148}$

In resolving the issue of arbitrability, the arbitrator and the court apply different standards. The court, which makes the initial determination, must find explicit language or the "most forceful evidence" of intent to deny arbitrability; the arbitrator does not have to overcome such a presumption but

142. See United Steelworkers v. Warrior \& Gulf Nav. Co., 363 U.S. 574, 578 (1960).

143. See generally Shulman, supra note 13; Wellington, Judge Magruder and the Labor Contract, 72 Harv. L. Rev. 1268, 1281 (1959); Cox, Reflections Upon Labor Arbitration, 72 HARV. L. REV. 1482 (1959).

144. See Jack Meilman, 34 L.A. 771 (1960) ( $\$ 109,588.96$ award to union as damages for illegal plant removal).

145. 363 U.S. 574 (1960).

146. 363 U.S. 574,575 (1960).

147. See note 125 supra.

148. See Gregory, The Law of the Collective Agreement, 57 MrcH. L. REv. 633, 650 (1959); but cf. Vulcan-Cincinnati Inc. v. United Steelworkers, 48 L.R.R.M. 2008, 2011 (6th Cir. 1961). Drake Bakeries v. Bakery Workers, 47 L.R.R.M. 2612 (2d Cir. 1961); McCarroll v. Los Angeles County Dist. Council of Carpenters, 49 Cal. 2d 45, 315 P.2d 322 (1957), cert. denied, 355 U.S. 932 (1958). 
bases his finding on the weighing of possibly conflicting indicia of intent.149 In light of this distinction, the arbitrability of a breach of a no-strike clause dispute will usually be determined by the arbitrator since there are few agreements which clearly exclude such disputes from the scope of its broad arbitration clause. ${ }^{150}$ When the dispute has been referred to the arbitrator, however, he may decide that the parties did not intend the question of the breach to be arbitrable after all. ${ }^{151}$ Thus, where the parties' intent regarding the court's competency is not absolutely clear from the agreement a court initially presented with an alleged breach of a no-strike promise should grant a stay, rather than dismiss, on the contingency that the claim might be returned to it by an umpire ultimately finding himself devoid of jurisdiction. ${ }^{\mathbf{1 5 2}}$

The occurrence of this latter contingency may frustrate an employer's attempt to secure quick injunctive relief where available, since the time between the granting of the stay and the return of the action to the court would be added to the normal length of the judicial process. ${ }^{153}$ If the dispute is sent directly to the arbitrator, however, thereby by-passing the earlier and possibly time-consuming grievance proceedings, there is no reason why this delay need be crucial. ${ }^{154}$ This short cut to arbitration would seem warranted by the fact that there has been a demonstrable breakdown in the normal economic relationship of the parties and that preliminary negotiation already proven un-

149. United States v. Warrior \& Gulf Nav. Co., 363 U.S. 574, 585 (1960). See also Cox; supra note 143, at 1503-07; Shulman, supra note 131.

150. See Gregory, supra note 148 , at 650 . But see Vulcan-Cincinnati, Inc. v. United Steelworkers, 289 F.2d 103 (6th Cir. 1961) (holding a no-strike clause not arbitrable and distinguishing the Steelworkers cases) ; accord, Sinclair Ref. Co. v. Atkinson, 48 L.R.R.M. 2045 (7th Cir. 1961).

151. See Note, 70 YALE L.J. 611,616 (1961). A reading of the three Steelworkers cases, supra note 1, leads to the conclusion that a high degree of deference is to be paid the arbitrator as the tribunal primarily responsible for the interpretation of the collective agreement. A necessary corollary of this conclusion would appear to be his ability to make a finding as to the meaning of the contract which would withstand judicial attack. Such a finding would be in the nature of an award, which would be specifically enforced. See United Steelworkers v. Enterprise Wheel and Car Corp., 363 U.S. 693 (1960) ; Gregory, supra note 148, at 648 .

152. See Note, 66 YALE L.J. 284, 291 n.40 (1956) ; McCarroll v. Los Angeles County Dist. Council of Carpenters, 49 Cal. 2d 45, 315 P.2d 322, 333 (1957), cert. denied, 355 U.S. 932 (1958). See also 66 YALE L.J. at 291 n.41, raising the question of the applicability of the stay provision of the United States Arbitration Act, 9 U.S.C. $\$ 3$ (1958).

153. Further delay may arise where provision is made for the appointment of an arbitrator after a lapse of time. See 2 CBNC $\$ 51: 341$.

154. See United Steelworkers v. Warrior \& Gulf Nav. Co., 363 U.S. 574 (1960) (court apparently ordering arbitration without regard to previous steps of the grievance procedure).

Where a contract provides arbitration as a last step in a grievance procedure, the federal courts should compel initial recourse to this process. This defers to the method legislated by the parties and it acknowledges the majority rule principle underlying the whole bargaining process.

Gregory, supra note 148, at 650 . 
successful should not be needlessly duplicated. The lapse of time may also be reduced if the parties have provided for a permanent umpire. ${ }^{155} \mathrm{~A}$ permanent umpire is more likely to predetermine his jurisdiction with respect to the no-strike clause or at least to have enough information as to intent of the parties readily available to render a quick decision. Should no permanent umpire be provided for, the problem is of course more complex. There is no reason, however, why the burden of alleviating such delay should not be placed squarely on the employer. His failure to elicit from the union a definitive contractual statement regarding the arbitrability of potential disputes would be but another manifestation of the parties' relative bargaining strength. ${ }^{150}$ Similarly, the delay which cannot be avoided by the above means is a direct consequence of the employer's own decision to institute an action in court rather than submit the claim initially to an arbitrator.

\section{Remedies}

The ultimate value of the contractual no-strike promise depends upon the ability of the employer to take direct action against the striking employees ${ }^{157}$ or secure from some tribunal effective remedies for an ascertainable breach. More than one-third of all collective bargaining agreements contain specific clauses authorizing the employer to discipline or discharge employees guilty of breaching the no-strike clause. ${ }^{158}$ Whether or not direct action against employees ostensibly violating a contractual no-strike promise is expressly authorized by the contract, however, the union or the particular employees will

155. See supra note 138.

156. This should be distinguished from bargaining to secure one tribunal rather than another. The emphasis here is to secure a clear and unambiguous statement of the tribunal, whichever it is. Compare cf. Paragraph 51, Collective Agreement, United Popular Dress Manufacturer's Association with I.L.G.W.U. and Dress Maker's Joint Council, set out at note 133 supra.

157. See generally Note, 106 U. PA. L. Rev. 999 (1958); Fulda, The No Strike Clause, 21 Gro. WASH. L. REv. 127, 157-70 (1952).

158. 2 CBNC $\S 77: 4$.

Since breach of contract is an unprotected activity under Taft-Hartley, the employer need not rely on a written concession of the union before he can take disciplinary measures against striking individuals. NLRB v. Sands Mfg. Co., 306 U.S. 336 (1939).

Where the penalties specifically set forth in the disciplinary clause are less severe than discharge, for example a warning, layoff or loss of seniority rights, it would seem reasonable to presume that the employer has bargained away his right to discharge guilty employees. See Note, 106 U. PA. L. REv. 999, 1003 (1958) (stating that absent a clause to the contrary, an employer would be limited to the contractually stated disciplinary action and could not assess money damages).

But see Louisville \& Nashville R.R. v. Brown, 252 F.2d 149 (5th Cir.), cert. denied, 356 U.S. 949 (1958) (individual employees are liable for damages caused by a wildcat strike falling under the province of the Railway Labor Act, 44 Stat. 577 (1926), as amended, 45 U.S.C. $\S \S 151-63,181-88$ (1958)). The decision has been sharply criticized. See Note, 59 Colum. L. Rev. 177 (1959); Gwen, Section 301, Arbitration and the NoStrike Clause, 11 LAB. L.J. 1005, 1017-20 (1960). 
in most circumstances attempt to deny the employer the right to make a unilateral determination of such issues as the breach, the employee's participation therein and the penalty to be imposed. ${ }^{159}$ Therefore, more than one-half of all collective agreements contain some procedure which the employer must follow prior to disciplining employees. ${ }^{180}$ Some provide for joint union-management administration of the disciplinary process. ${ }^{161}$ But the most common method of limiting the employer's freedom in this area is through review and control of his actions by an appropriate tribunal.

Since strike activity in preacn ot contract is unprotected under the TaftHartley Act, ${ }^{162}$ the NLRB has little opportunity for consistent and effective review of employer discipline of no-strike clause violators, ${ }^{163}$ except perhaps in Mastro situations where the strike itself was precipitated by an employer unfair labor practice. ${ }^{104}$ Normally, then, wide discretion is accorded the employer by the Board. Assuming a finding that the strike is an unprotected activity, the employer is even permitted by Taft-Hartley to single out for punishment the strike leaders whether union officers, shop stewards or rank and file spokesmen, and ignore the bulk of employees. ${ }^{165}$

Although such disciplinary action against striking employees may not violate the Taft-Hartley Act, it may be subject to challenge in the courts as a breach of the collective agreement. ${ }^{166}$ But such issues are particularly well suited to arbitration, and the overwhelming majority of labor agreements specifically provide for review of disciplinary measures within the contractual disputesettling procedure. ${ }^{107}$ Even in the absence of such express directives, a strong presumption that questions regarding disciplinary measures are subject to arbitration arises under the Steelworkers doctrine. ${ }^{168}$

Some arbitrators, whether specifically restricted by the contract or not, have limited their review of disciplinary questions to the participation of the in-

159. See Note, 106 U. PA. L. REv. 999, 1000 (1958).

160. 2 CBNC $\S \S 40: 4,40: 61$.

161. 2 CBNC \& $40: 241$.

162. See NLRB v. Sands Mfg. Co., 306 U.S. 336 (1939). See also UEW v. NLRB, 223 F.2d 338 (D.C. Cir. 1955), cert. derried, 350 U.S. 981 (1956), rehearing denied, 351 U.S. 915 (1956).

163. See Joseph Dyson \& Sons, 72 N.L.R.B. 445, 447 (1947) ; Plastic Line, Inc., 123 N.L.R.B. 1471 (1959), reversed sub nom. Plasti-Line, Inc. v. NLRB, 278 F.2d 482 (6th Cir. 1960).

164. Mastro Plastics Corp. v. NLRB, 350 U.S. 270 (1956), rehearing denied, 351 U.S. 980 (1956).

165. See, e.g., NLRB v. American Mfg. Co., 203 F.2d 211 (5th Cir. 1953) ; PlastiLine, Inc. v. NLRB, 278 F.2d 482 (6th Cir. 1960) ; American Gilsonite Co., 121 N.L.R.B. 1514 (1958) ; Administrative Rulings of NLRB General Counsel, Case No. F-854, 1959; Note, 106 U. PA. L. REv. 999, 1001 (1958). The employer would, however, appear to violate LMRA $\S 8(\mathrm{~b})(3)$ if he fired or rehired on the basis of union, rather than strike, activity.

166. See Note, 106 U. PA. L. REv. 999, 1000 (1958).

167. 2 CBNC $\S \S 51: 7,40: 4,40: 121$.

168. See supra note 39 and accompanying text. 
dividual in the strike; others have also reviewed the severity of the penalty imposed by the employer. ${ }^{169}$ The latter approach seems more desirable where the parties have not contracted to vest the sole right to ascertain the nature and degree of discipline in the employer. The presumed expertise of the arbitrator makes him uniquely qualified to pull together and evaluate such diverse elements as the gravity of the strike ${ }^{170}$ and claims of employer condonation (such as alleged promises of full reinstatement with no loss of status if the strike is terminated). ${ }^{171} \mathrm{He}$ also proceeds with knowledge that the parties must "live" together following the settlement of this dispute, a circumstance rarely considered in the resolution of most commercial contract disputes.

While the development of a fair and effective disciplinary system is a necessary adjunct to the enforceability of a no-strike promise, recourse to such procedures is often impractical or inexpedient. The employer may be unwilling to replace key employees; discharge or discipline of individual workers may unduly prejudice the employer's future relations with the workers and the union; or actual responsibility for the breach may rest on members of the union hierarchy beyond the reach of employer discipline. Furthermore, individual discipline in no way compensates for financial losses incurred by the strike. Thus other remedies are frequently invoked against the union itself in place of or in conjunction with individual dismissal when a contractual nostrike clause is breached.

One such remedy, apparently seldom used, is rescission of the entire collective agreement by the employer on the theory that a violation of the nostrike clause is a material breach of the contract. ${ }^{172}$ Thus, in the Marathon Electric case ${ }^{173}$ the union called a strike over the issue of a general wage increase ${ }^{174}$ during the term of a contract which contained a grievance and arbitration clause as well as a no-strike provision. The employer notified the union that the contract had been terminated and discharged the striking workers. ${ }^{175}$ The union filed a charge with the NLRB, claiming the company had committed unfair labor practices by terminating the labor agreement, dis-

169. See Note, 106 U. PA. L. Rev. 999, 1001 (1958).

170. Id. at 1008 .

171. See Bechtel Corp., 127 N.L.R.B. 891 (1960); NLRB v. Dorsey Trailers, Inc., 179 F.2d 589 (5th Cir. 1950); Plasti-Line, Inc. v. NLRB, 278 F.2d 482 (6th Cir. 1960).

172. See Fulda, The No Strike Clause, 21 Geo. Wast. L. Rev. 127, 143-44 (1952); Ezrine, Nadir of the No-Strike Clause, 8 LAB. L.J. 769, 780 (1957).

Strictly construed, the doctrine of rescission is applicable only to a mutual agreement by the parties to discharge and terminate their duties under the contract. ConsIN, CoNTRACTS $\$ 1236$ (1952). Unilateral seyerance of the contract is more accurately described as the discharge of future obligations.

Doctrinal problems are avoided when the parties have contracted for an optional termination of the agreement upon the breach of a no-strike (or lockout) clause. See 2 CBNC $\S \S 77: 275,36: 482$.

173. Local 1113, UEW v. NLRB, 223 F.2d 338 (D.C. Cir. 1955), cert. denticd, 350 U.S. 981 (1956), rehearing denied, 351 U.S. 915 (1956).

174. 223 F.2d at 340 .

175. Id. at $340-41$. 
criminatorily discharging union members and refusing to bargain. ${ }^{176}$ The Board found against the union on each of these charges. ${ }^{177}$ In upholding the Board, the Court of Appeals for the District of Columbia assumed arguendo that the contract was not terminated by the union's action but by the employer's election to rescind. ${ }^{178}$ Invoking general contract law, the court noted that one party may rescind a contract if the other party is guilty of a material breach. The violation of a no-strike ban, it reasoned, constituted a material breach since prevention of strikes is "one of the principle purposes of labor contracts and of the Taft-Hartley Act and a no-strike clause is the principal advantage an employer derives from a collective agreement. ${ }^{179} \mathrm{By}$ this result, the court circumvented the mandatory notice requirements of section 8 (d) for terminating a labor contract, ${ }^{180}$ for it necessarily assumed that an employer need not comply with section 8 (d) when the union had previously violated the same statutory provision by striking over a fixed term of the contract. ${ }^{181}$ The court viewed the strike as constituting a "refusal to bargain" as well as a breach of contract, ${ }^{182}$ thereby invading the province of the NLRB; ${ }^{183}$ and on the basis of this refusal to bargain, it held that the employer's statutory duties under 8 (d) were discharged.

Thus, a trial court would not be justified in applying the rescission doctrine of Marathon in a breach of contract suit where there has been no prior finding by the Board that the union's activities constituted an unfair labor practice. ${ }^{184}$ A finding by the court of a breach of contract by the union would not be sufficient since the legislative history of Taft-Hartley clearly shows that a breach of contract does not constitute a per se unfair labor practice. ${ }^{185}$ The distinction between a breach of contract and an unfair labor practice is crucial, and to say that upon the union's breach of the contract alone there is nothing to which section 8(d) can apply begs the question. Courts ought not to base an abrogation of the specific requirements of section 8 (d) on merely the general mandate of section 301 to enforce the collective agreement.

Assuming that the Board has found a union unfair labor practice, the employer may often damage his bargaining position if he elects to rescind the agreement. He would gain an advantage only if a shift in economic conditions

176. 106 N.L.R.B. 1171 (1953).

177. 223 F.2d at 340-44. However, the Board upheld the trial examiners' finding that the company did commit several unfair labor practices involving the recognition of a new union. 106 N.L.R.B. at 1175.

178. 223 F.2d at 341 .

179. Ibid.

180. See note 22 sitpra.

181. 223 F.2d at $341-42$.

182. Id. at $342-44$.

183. See supra note 90 and accompanying text.

184. The Board decision in Marathon nowhere alludes to any unfair labor practice committed by the union. Cf. LMRA $\S 10$ (d), indicating the scope of judicial review in unfair labor practice cases.

185. 1 LEg. Hist. 545-46. 
or in the relative strength of the parties has occurred since the signing of the original contract; for example, the incumbent union no longer represents a majority of the employees and either no new union can obtain majority representation and certification or a more "friendly" union is certified to represent the new employees. ${ }^{186}$ Should the old union still represent a majority of the employees, or a new union be certified, the duty to bargain over terms and conditions of a new contract would be statutorily imposed upon the employer ${ }^{187}$ and the union presumably could continue or renew the strike. ${ }^{188}$ In such situations, only the old union would benefit from a rescission since an employer who rescinds a collective agreement is barred from asserting any contractual right or relief he may otherwise be entitled to seek. ${ }^{189}$

Considerations of labor policy distinguishing a collective bargaining agreement from a commercial contract argue against the application of the rescission doctrine in this context. ${ }^{190}$ Even without an effective no-strike clause, the

186. It is an unfair labor practice for an employer "to refuse to bargain collectively with the representatives of his employees, subject to the provisions of section 9a." LMRA $\S 8(a)(5)$. See also LMRA § 9.

187. After the discharge of its member employees and the "rescission" of the contract, the union in the Marathon case no longer represented a sufficient number of employees to raise a question of the duty of the Company to bargain for a new contract. $223 \mathrm{~F} .2 \mathrm{~d}$ at 344. However, the Board's finding of an unfair labor practice against the employer for recognizing a new union would seem to imply that the contract "rescission" did not effectuate a decertification of the statutory bargaining representative for purposes of LMRA \$ 9. 106 N.L.R.B. 1171 (1953).

188. When the union is engaging in an illegal strike, the Board has held that the employer is under no duty to bargain prior to the termination of the union's conduct. E.g., Higgins Inc., 90 N.L.R.B. 1821 (1950); Charles E. Reed \& Co., 76 N.L.R.B. 548 (1948). It would seem, however, that the illegality of the union's conduct would be removed once the contract has been resumed since the unprotected nature of the strike stemmed from a violation of the terms of the agreement.

189. Boeing Airplane Co. v. Local 751, IAM, 188 F.2d 356 (9th Cir.), cert. denied, 342 U.S. 821 (1951). The contract in the Boeing case contained a no-strike clause which the court in a prior decision had found breached by the union. Boeing Airplane Co. v. NLRB, 174 F.2d 988 (9th Cir. 1949). Cf. Ezrine, supra note 172, at 778-79.

190. See Lewis v. Benedict Coal Corp., 361 U.S. 459 (1960), where the trustees of a union welfare fund, meeting the requirements of LMRA $\S 302(\mathrm{c})(5)$, brought an action against the Benedict Coal Corp. to recover the balance of a sum owed to the fund by the company. Benedict characterized the trustees as third party beneficiaries of the collective bargaining agreements and asserted that it should be allowed to set-off against the claim of the trustees. $I d$, at 462,464 . The Court, in refusing to accept this characterization, noted that the welfare fund was designed to aid employees and their families in time of need and implied among other things that allowing Benedict to curtail its payments to the fund would work a hardship not intended by the contracting parties. Id. at 468-69. Moreover, the Court asserted that the national labor policy underlying LMRA § 301(b) required that a money judgment be enforced against the union as an entity, whereas allowing the claimed set-off here would have affected the interests of many individuals who, by virtue of retirement or their status as dependents, would have no voice in union affairs. 361 U.S. at 470 . See also Shulman, Reason, Contract, and Law in Labor Relations, 68 HARv. L. Rev. 999 (1955) ; Cox, Reflections Upon Labor Arbitration, 72 HARv. L. REv. 1482, 1498-99 (1959). 
labor contract is of central importance in promoting industrial stability. ${ }^{191}$ The contractual remedy of rescission is designed to sever relations between the parties, perhaps an effective device in a commercial context, but not well suited to the continuing relationship between employer and employees. Furthermore, the employer may seek damages or an injunction, ${ }^{192}$ and invoke disciplinary measures, ${ }^{193}$ which would appear entirely adequate to redress any injury he has incurred and to dissuade the union and its members from breaching the no-strike promise in the future.

The power of the federal courts to award damages for breach of contract seems well established ; ${ }^{\mathbf{1 0 4}}$ the role of state courts in enforcing labor contracts under section 301 of Taft-Hartley is less clear. The prevailing view that state courts have concurrent jurisdiction to apply federal substantive law has been presented persuasively by Justice Traynor in McCarroll $v$. Los Angeles County Dist. Council of Carpenters. ${ }^{195}$ The substitution of the arbitrator for the courts need not preclude the employer from obtaining damages. ${ }^{196}$ Monetary awards are not common but have been rendered when the employer has incurred serious financial loss as a result of the breach. ${ }^{197}$ Indeed, the expertise of the

191. The importance of the collective agreement in fostering a federal labor policy is manifest throughout the Labor Management Relations Act. Thus, for example, a requirement of good faith bargaining necessitates "the execution of a written contract incorporating any agreement reached. .. ," LMRA § 8(d), in addition to making any attempt to modify or terminate the agreement during its term an unfair labor practice, see Local 3 , United Packinghouse Workers v. NLRB, 210 F.2d 325 (8th Cir.), cert. denied, 348 U.S. 822 (1954). Cf. NLRB v. Lion Oil Co., 352 U.S. 282 (1957). See also Textile Workers Union v. Lincoln Mills, 353 U.S. 448 (1957) and the Steelworkers cases note 2 supra, construing the enforceability of the contract under LMRA $\S 301$.

192. See notes 195-248 infra and accompanying text.

193. See notes 157-61 supra and accompanying text.

194. See Lewis v. Benedict Coal Corp., 361 U.S. 459, 464 (1959), affirming by an equally divided Court, without discussion on this point, the decision of the Sixth Circuit that the union breached an implied promise not to strike. Cf. Local 25, Teamsters Union v. W.L. Mead, Inc, 230 F.2d 576 (1st Cir. 1956), cert. denied, 352 U.S. 802 (1956) (a damage award of $\$ 359,000$ assessed against the union for breach of an "implied" no strike clause). See also Textile Workers Union v. Lincoln Mills, 353 U.S. 448 (1957) ; Steelworkers cases note 2 supra; Comment of Senator Taft, 2 LEG. Hrst. 1539.

195. McCarroll v. Los Angeles County Dist. Council of Carpenters, 49 Cal. 2d 45, 6364, 315 P.2d 322 (1957), cert. denied, 355 U.S. 932 (1958). But see Charles Dowd Box Co. v. Courtney, 169 N.E.2d 885 (Mass. 1960), cert. granted, 81 Sup. Ct. 699 (1961); Local 174, Teamsters Union v. Lucas Flour Co., 356 P.2d 1 (Wash. 1960), cert. granted, 81 Sup. Ct. 902 (1961). See also Wellington, Labor and The Federal System, 26 U. CrI. L. REv. 542, 551-60 (1959).

196. Cox, Reflections Upon Labor Arbitration, 72 HARv. L. Rev. 1482 (1959):

The arbitrator's power to fashion remedies is so generally accepted today that ... . the power to determine whether a collective-bargaining agreement has been violated carries the implied power to grant a remedy for the violation.

Id. at 1494.

See also Gregory, The Law of the Collective Agreement, 57 Mrcm. L. REv. 633, 646 (1958). Cf. Signal-Stat Corp. v. Local 475, UEW, 235 F.2d 298 (2d Cir. 1956).

197. See Oregonian Publishing Co., 33 LAB. ARB. 574 (1959) (arbitrator has power to award damages for strike in violation of the contract), In re Motor Haulage $\mathrm{Co}_{3} 6$ I,AB, 
arbitrator, his personal knowledge of the industrial situation and his ability to marshal facts unhindered by judicial rules of evidence make him particularly well suited to assure the remedial nature of the damages.

Rather than award damages, the arbitrator may order the union to cease the strike activity and return to work. ${ }^{198} \mathrm{He}$ may be motivated by a number of factors: a desire to reduce industrial friction by returning the parties to more normal conditions; a desire to minimize the loss to the employer and to protect the union against the burden of a large money judgment; a realization that the loss cannot be adequately measured or that the union is judgment proof. ${ }^{199}$ But for all intents and purposes, a court called upon to enforce the arbitrator's order to end the strike is entertaining an action for an injunction ${ }^{200}$ denied by the Norris-LaGuardia Act. ${ }^{201}$ In United Steelworkers $v$. Enterprise Wheel \& $\mathrm{Car} \mathrm{Co.}^{202}$ however, the Supreme Court upheld the specific enforcement of an arbitration award under section 301 with no mention of Norris-LaGuardia. Application of Norris-LaGuardia to prevent the enforcement of arbitration awards would seem misplaced, for the purpose of that Act -the withdrawal of the judiciary from the role of formulating federal labor law and policy 208 -would not be served. Arguably, it is the arbitrator who

ARs. 720, aff'd sub. nom. Motor Haulage Co. v. Int'l Bhd. of Teamsters, 272 App. Div. 382, 71 N.Y.S.2d 352 (1st Dep't 1947); Canadian Gen. Elec. Co., 18 LAB. ARB. 925 (1952) (monetary penalties against employees for violation of no-strike clause) ; Newark Newsdealers Supply Co., 20 LAB. ARb. 476 (1953); Cox, supra note 196, at 1494; Note, 66 Y YLE L.J. 284, 292 n.44 (1956). See also Jack Meilman, 34 LAB. ARB. 771 (1960) (damages for run away shop).

198. Ruppert v. Egelhofer, 3 N.Y.2d 576, 148 N.E.2d 129 (1958) holding that an arbitrator could enjoin strike activity in breach of contract despite the existence of a state anti-injunction statute. The decision was based on the court's interpretation of the parties' intent in light of the fact that the contract provided for a speedy rendition of an arbitrator's award. Id. at 581, 148 N.E.2d at 130; see Note, 58 CoLuM. L. REv. 908 (1958); Givens, Section 301, Arbitration and the No-Strike Clanse, 11 LAB. L.J. 1005, 1014-15 (1960).

On the ability of an arbitrator to fashion a remedy, see Cox, supra note 196, at 1494.

199. Cox, Current Problems in the Law of Grievance Arbitration, 30 Rocky Mr. L. REv. 247 (1958):

The statute does not specify the remedy but an injunction is the only practical relief against a strike. Damages are inadequate because the injury to the business cannot be measured accurately. Furthermore, an employer can rarely afford to exacerbate labor-management relations by suing a union made up of his employees after the end of the strike.

Id. at 255 .

See also Meltzer, The Supreme Court, Congress, and State Jurisdiction Over Labor Relations: II, 59 CoLuM. L. REv. 269, 281 (1959).

. 200. See Ruppert v. Egelhofer, 3 N.Y.2d 576, 148 N.E.2d 129 (1958).

201. 47 Stat. 70 (1932), as amended, 29 U.S.C. $\$ \S 101-15$ (1958).

202. 363 U.S. $593(1960)$.

203. Comment, 70 Y Panama S.S. Co., 362 U.S. 365, 369 n.7 (1960) (Norris-LaGuardia "was prompted by a desire ... to withdraw federal courts from a type of controversy for which many believed they were ill-suited and from participation in which, it was feared, judicial prestige might suffer"). See generally Frañ KFurter \& Greeñe, The Labor InJunction (1930). 
has adjudicated the breach and enjoined the strike, not the court $;^{204}$ the latter merely formalizes an award which is not self-enforcing in much the same manner it effectuates a cease and desist order of the NLRB. ${ }^{205}$

Permitting courts to enjoin strikes indirectly by granting specific enforcement of arbitration awards is one manifestation of the interaction between Norris-LaGuardia and Section 301; a more common instance of this interaction occurs when management seeks to enjoin the strike directly. As enacted in 1932, Norris-LaGuardia was intended to limit the role of the federal judiciary in the formulation of labor policy by withdrawing power to enjoin nonviolent strike activity. ${ }^{208}$ The passage of section 301 in 1947 and its subsequent interpretation by the Supreme Court in Lincoln Mills nine years later as a mandate to develop a federal substantive law of labor contracts represents a partial shift from the philosophy of Norris-LaGuardia by the reintroduction of the judiciary into the area of federal labor law-making. ${ }^{207}$ To maintain the balance of power between labor and management secured by post NorrisLaGuardia legislation, Congress felt it imperative to hold the parties to their contractual promises. In light of this shift in philosophy, the reasoning of the Tenth Circuit in Teamsters Union v. Yellow Transit Lines, ${ }^{208}$ justifying the issuance of a strike injunction seems persuasive:

.... it is one thing to utilize an injunction decree for the negative purpose of interfering with freedom of association, self-organization and designation of representatives to negotiate the terms and conditions of employment. It is another to utilize the judicial process to preserve and vouchsafe the fruits of a bargain which the parties have freely arrived at through the exercise of collective bargaining. ${ }^{209}$

But in limiting the application of Norris-LaGuardia, Yellow Transit cannot be grouped with Lincoln Mills and Steelworkers where orders to arbitrate were issued, for Norris-LaGuardia clearly encourages recourse to the arbitration process. ${ }^{210}$ Furthermore, there is evidence that the framers of Taft-Hartley, though rendering Norris-LaGuardia inapplicable in several instances to

204. See Givens, supra note 198, at 1014; cf. Note, 58 Colum. L. Rev. 908 (1958).

205. The analogy, however, is not complete since the Taft-Hartley Act has specifically withdrawn the prohibitions of Norris-LaGuardia with respect to court enforcement of NLRB orders. LMRA $\$ \$ 10$ (j) \& (1), 61 Stat. 149 (1947), as amended, 29 U.S.C. $\$ 160(j)$ (1958), 29 U.S.C.A. § 160(1) (Supp. 1960).

206. 47 Stat. 70-73 (1932), as amended, 29 U.S.C. $\$ \S 101-15$ (1958). See generally Comment, 70 Yale L.J. 70 (1960); Note, 72 HaRV. L. Rev. 354 (1958).

207. Comment, 70 Yale L.J. 70 (1960).

208. 282 F.2d 345 (10th Cir. 1960), cert. granted, 81 Sup. Ct. 378 (1961).

209. 46 L.R.R.M. at 2918; accord, American Smelting \& Ref. Co. v. Tacoma Smeltermen's Union, 175 F. Supp. 750 (D. Wash. 1959).

210. "No restraining order or injunctive relief shall be granted to any complainant who has failed ... to make every reasonable effort to settle such dispute either by negotiation or with the aid of any available governmental machinery of mediation or voluntary. arbitration."

Norris-LaGuardia Act § 8, 47 Stat. 72 (1932), 29 U.S.C. § 108 (1958). 
avoid conflict with the directives of the LMRA, ${ }^{211}$ purposely deleted from the committee draft of section 301 a provision withdrawing Norris-LaGuardia from the area of contract enforcement. ${ }^{212}$ Thus, the argument raised by $Y$ ellow Transit cannot be reconciled with the legislative history and express language of Norris-LaGuardia. ${ }^{213}$

It might also be suggested that the Supreme Court accommodate the apparent conflict between Norris-LaGuardia and section 301 as it did in Brotherhood of R.R. Trainmen v. Chicago River \& Ind. R.R.,214 where a strike in violation of the compulsory arbitration provision of the Railway Labor Act was enjoined. ${ }^{215}$ But Chicago River and Yellow Transit are not two of a kind. The legal history of the 1934 amendments of the RLA indicates that its draftsmen gave no thought to the provisions of Norris-LaGuardia enacted two years before. ${ }^{216}$ In contrast, both the legislative history and final text of the LMRA are replete with references to the power of the courts to issue injunctions notwithstanding the prohibitions of Norris-LaGuardia. ${ }^{217}$ Moreover, the Supreme Court has not only manifested its intention to confine Chicago River

211. See note 205 supra; LMRA §§ 206-10, 61 Stat. 155 (1947), 29 U.S.C. $\S \S 176-80$ (1958) (national emergency dispute injunctions), LMRA $\S 302,73$ Stat. 537 (1959); 29 U.S.C. $§ 186$ (Supp. 1960) (covering pension and welfare funds); Comment, 70 Yale L.J. 70, 97-98 (1960).

212. The Senate version of what is now LMRA $\S 301$ would have made a breach of the collective bargaining agreement an unfair labor practice enjoinable under LMRA $\S$ 10(j). 1 LEG. Hist. 99. The House version vested power to adjudicate breaches of the agreement in the courts, specifically authorizing judicial injunctions and making NorrisLaGuardia inapplicable. 1 LEG. Hrst. 158, 201. The conference committee accepted the House version but deleted the provision repealing Norris-LaGuardia. 1 LEG. HIST. 505.

213. It was the persuasiveness of this legislative history which led Judge Clark to rule that Norris-LaGuardia barred a federal court from enjoining a strike in violation of a nostrike clause. A.H. Bull S.S. Co. v. Seafarers' Union, 250 F.2d 326, 331-32 (2d Cir. 1957), cert. denied, 355 U.S. 932 (1958); see also Sinclair Ref. Co. v. Atkinson, 48 L.R.R.M. 2045 (7th Cir. 1961); W.L. Mead, Inc. v. International Bhd. of Teamsters, 217 F.2d 6 (1st Cir. 1954); In re Third Ave. Transit Corp., 192 F.2d 971 (2d Cir. 1951) ; Associated Tel. Co. v. Communication Workers, 114 F. Supp. 334 (S.D. Cal. 1953), Comment, 70 YaIE L.J. 70, 97-98 (1960); Note; 72 HaRv. L. Rev. 354, 364-68 (1958). Givens, Scction 301, Arbitration and the No-Strike Claute, 11 LAB. L.J. 1005, 1015 (1960).

214. 353 U.S. 30 (1957) (enjoining a strike over grievances which had been submitted to the National Railroad Adjustment Board). The Board is empowered to render a final decision on grievances which constitute "minor" as opposed to "major" disputes. See Comment, 70 YaLE L.J. 70,77 (1960). Upon submission by either party, arbitration of "minor" grievances is compulsory. Railway Labor Act $\S 3$ (i) \& (m), as amended, 48 Stat. 1191 (1934), 45 U.S.C. $\$ \S 153(i) \&(m)$ (1958). In this light the court reasoned that the Norris-LaGuardia and Railway Labor Acts must be accommodated as part of a pattern of national labor legislation. To have held otherwise would have rendered the compulsory jurisdiction of the Railroad Adjustment Board meaningless. See Note, 109 U. PA. L. REv. 293, 301-03 (1960).

215. See Cox, Current Problems in the Lawe of Grievance Arbitration, 30 Rocky Mr. L. Rev. 247, 252-56 (1958); Gregory, The Law of the Collective Agreement, 57 Mrcr. L. REv. 635, 645 (1959).

216. Comment, 70 YALE L.J. 70, 77, 97 (1960).

217. Ibid. 
to its facts, ${ }^{218}$ but has expressed in dictum its feeling that, policy considerations notwithstanding, Congress, not the Court, is the forum to effectuate a change in the scope of Norris-LaGuardia. ${ }^{219}$

By its terms Norris-LaGuardia is applicable to federal courts alone, ${ }^{220}$ yet judicial extension of its provisions to state courts exercising concurrent jurisdiction over section 301 suits is not unreasonable. Admittedly, an argument for securing uniformity of result under section 301 regardless of the forum in which suit is brought flows easily from the holding of Lincoln Mills. ${ }^{221}$ Assuming that state law must be subordinated to the federal law of labor contracts, and this federal law in turn is to be governed by federal labor policy, then Norris-LaGuardia, as an integral part of federal labor policy, should govern states applying federal labor law. ${ }^{222}$ Such symmetry, whether grounded in the application of a reverse Erie R.R. v. Tompkins theory or in concern to avoid uncertainty and disparity in litigants' rights, ${ }^{223}$ can be secured only by disregarding the legislative history of Taft-Hartley. In evaluating the history, the California Supreme Court in McCarroll v. Los Angeles County Dist. Council of Carpenters ${ }^{224}$ found that Congress was not only aware of the existence of an independent body of state remedies for breaches of labor contracts but was desirous of strengthening, not emasculating, these sanctions. ${ }^{225}$ In light of this recognition and apparent approval of the states' independent interest in labor contract matters and the absence of any specific congressional

218. Order of R.R. Telegraphers v. Chicago \& N.W. Ry., 362 U.S. 330, 341 (1960) (refusing to enjoin a strike over a major dispute). Cf. note 209 supra; Comment, 70 YaLE L.J. 70, 81 (1960). See also Sinclair Ref. Co. v. Atkinson, 48 L.R.R.M. 2045 (7th Cir. 1961).

219. Order of R.R. Telegraphers v. Chicago \& N.W. Ry., 362 U.S. at 342 :

It may be, as some people think, that Congress was unwise in curtailing the jurisdiction of federal courts in railroad disputes as it did in the Norris-LaGuardia Act. Arguments have been presented here pointing to the financial debilitation of the respondent Chicago \& North Western Railroad and to the absolute necessity for the abandonment of railroad stations. These arguments, however, are addressed to the wrong forum. If the scope of the Norris-LaGuardia Act is to be cut down in order to prevent "waste" by the railroads, Congress should be the body to do so. Such action is beyond the judicial province and we decline to take.

See Note, 109 U. PA. L. Rev. 293 (1960).

220. "[N]o court of the United States shall have jurisdiction ...." Norris-LaGuardia Act $\S 1,47$ Stat. 70 (1932), 29 U.S.C. $\S 101$ (1958). See McCarroll v. Los Angeles County Dist. Council of Carpenters, 49 Cal. 2d 45, 315 P.2d 322 (1957), cert. denied, 355 U.S. 932 (1958). Many state courts have passed "little" Norris-LaGuardia Acts. E.g., N.Y. CIv. PrAC. Act § 876(a).

221. See Gregory, supra note 215; but cf. Wellington, supra note 195; Meltzer, The Supreme Court, Congress, and State Jurisdiction Over Labor Relations: II, 59 Colvm.

L. Rev. 269 (1959) ; Comment, 70 YaLE L.J. 70, 100-02 (1960).

222. Comment, 70 Yale L.J. 70, 100 (1960).

223. Id. at 101 .

224. See note 195 supra and accompanying text.

225. See, e.g., 1 LEG. HIST. 422-23. 
intent to curtail exercise of the most effective of state remedies-the injunction, judicial extension of Norris-LaGuardia to state courts would be unwarranted.

If federal courts are in fact precluded from granting injunctions against strikes instituted in violation of a no-strike clause but state courts are not, a striking union may attempt to remove the case from a state court to a federal court ${ }^{226}$ and, if successful, move to dismiss the claim for an injunction as barred by Norris-LaGuardia. The jurisdictional requirements of the federal removal statute ${ }^{227}$ would be satisfied even though the pleadings are drawn solely in terms of state law, ${ }^{228}$ since Lincoln Mills has made it clear that federal substantive law governs in breach of labor contract suits. ${ }^{229}$

The fact that the jurisdictional requirements are satisfied, however, does not by itself determine the proper disposition of the union's petition for removal. The federal court must determine in addition whether Norris-LaGuardia affects the basic jurisdiction of the courts or whether it merely limits the exercise of equitable jurisdiction. ${ }^{230}$ If the basic jurisdiction of the court is denied, the action must be remanded to the state court; if the court assumes jurisdiction its inability to grant injunctive relief requires a dismissal on the merits. ${ }^{231}$ This latter course has been pursued in a line of federal cases exem-

226. Cf. Tool \& Die Makers Lodge 78 v. General Elec. Co., 170 F. Supp. 945 (E.D. Wis. 1959) (holding that an action can be removed from a state administrative agency to a federal court when the state makes breach of contract an unfair labor practice cognizable in a state court or agency). See Fitzsimmons, Removal Rights in Labor Litigation, 11 LAB. L.J. 137 (1960).

227. 28 U.S.C. $\S 1441$ (b) (1958).

228. It has been held that a federal court on removal can look behind the complaint to see if the union represents employees in an industry affecting commerce as required by Taft-Hartley. Fay v. American Systoscope Makers, Inc., 98 F. Supp. 278 (S.D.N.Y. 1951). This approach is based upon cases which hold that where jurisdiction depends upon the status of one of the parties, the court can ascertain that status independently of the complaint. E.g., Texas \& Pac. R.R. v. Cody, 166 U.S. 606 (1897) (a corporation); Winters v. Drake, 102 Fed. 545 (C.C.N.D. Ohio 1900) (federal nature of a receiver); Wood v. Drake, 70 Fed. 881 (C.C.D. Wash. 1893) (a marshal). It is also generally held that "the court may properly take judicial notice of any Federal laws necessarily brought into play by the allegations of the complaint, although specific reference to such laws has been omitted." S.E. Overton Co. v. International Bhd. of Teamsters, 115 F. Supp. 764, 768 (W.D. Mich. 1953). See, e.g., Southern Pac. Co. v. Stewart, 245 U.S. 359, 362 (1917); Dynamic Mfrs., Inc. v. Local 614, General Drivers Union, 103 F. Supp. 651, 652 (E.D. Mich. 1952); Downey v. Geary-Wright Tobacco Co., 39 F. Supp. 33 (E.D. Ky. 1941); but cf. Isbrandtsen Co. v. Schelero, 118 F. Supp. 579 (E.D.N.Y. 1954).

229. Textile Workers Union v. Lincoln Mills, 353 U.S. 448 (1957).

230. Cox, The Void Order and the Duty to Obey, 16 U. Crr. L. Rev. 86, 106-08 (1948).

231. Compare Pocahontas Terminal Corp. v. Portland Bldg. \& Constr. Trades Council, 93 F. Supp. 217 (D. Maine 1950), with Swift \& Co. v. United Packinghouse Workers, 177 F. Supp. 511 (D. Colo. 1959), and Hat Corp. v. United Hatters, 114 F. Supp. 890 (D. Conn. 1953) and Berrios v. Bull Insular Line, Inc., 109 F. Supp. 858 (D. Puerto Rico 1953) and Home Bldg. Corp. v. Carpenters Dist. Council, 53 F. Supp. 804 (W.D. Mo. 1943). Cf. American Optical Co. v. Andert, 108 F. Supp. 252 (W.D. Mo. 1952). See 
plified by Pocahontas Terminal Corp. v. Portland Bldg. \& Constr. Trade Council ${ }^{232}$ which held that while Norris-LaGuardia limits the power of a court to grant an injunction, it "does not deprive the court of jurisdiction to contsider cases in which such relief is asked for or to grant other than injunctive relief therein."233 But this reasoning has been specifically rejected by a majority of the federal courts which have considered this problem and chosen to remand rather than dismiss the cause on the merits. ${ }^{234}$ In Swrift $\&$ Co. v. United Packinghouse Workers, ${ }^{235}$ for example, the court specifically repudiated the analysis of Pocahontas and noted that ". . . it would be incongruous to hold that the case, insofar as it seeks injunctive relief, is removable and then shortly thereafter hold that part of the complaint is dismissed for lack of jurisdiction under Norris-LaGuardia."236 In addition, the majority's position is buttressed both by the wording of Norris-LaGuardia itself - "No court of the United States ... shall have jurisdiction to issue any restraining order or temporary or permanent injunction ..."237-and by its interpretation by the Supreme Court. ${ }^{238}$

Viewing Norris-LaGuardia as affecting basic jurisdiction and not merely as a limitation on the equitable powers of the court seems preferable from a policy standpoint. ${ }^{239} \mathrm{~A}$ dismissal of the cause on its merits in the federal court may deny the employer the opportunity to obtain relief in the state court. Until such time as Congress expressly precludes the application of independent state remedies in the area of federal labor law, ${ }^{240}$ it would seem improper for the federal courts to accept jurisdiction for the sole purpose of denying the relief sought. Nor does remission to the state court emasculate the policy behind the federal removal statute of affording defendant a federal forum when the complaint could originally have been brought in a federal court, ${ }^{241}$ for if removal was improper, original jurisdiction obviously did not exist. ${ }^{242}$ Thus, the choice is not framed in the manner contemplated by section 1441(b), between trial before a state or federal court, but between trial before a state court and dismissal of the claim. Furthermore, should the jurisdictional questions raised by Norris-LaGuardia be left unresolved, remission may be supported on an

Chafee, Some Problems of EQuity 364-80 (1950); Comment, 72 Harv. L. Rev. 354 (1958); Cox, supra note 230; Note, 71 Harv. L. REv. 1172, 1177 (1958).

232. 93 F. Supp. 217 (D. Maine 1950).

233. Id. at 225 .

234. See note 231 supra.

235. 177 F. Supp. 511 (D. Colo. 1959).

236. Id. at 515 .

237. 47 Stat. 70 (1932), 29 U.S.C. § 101 (1958).

238. United States v. UMW, 330 U.S. 258 (1947).

239. But cf. Cox, The Void Order and the Duty to Obey, 16 U. CrI. L. Rev. 86, 105 (1948).

240. See notes 220-25 supra and accompanying text.

241. See generally Moore, Coammentary On the United States Judicial Code If $0.03(31)$, at $220-21$ (1949).

242. See note 231 supra. 
additional ground. It is a well established rule that removal should be denied in cases where the jurisdiction of the federal court is doubtful. ${ }^{243}$

A new dimension is added to the removal problem if a prayer for injunctive relief is joined with a claim for damages. Although it may be argued that the federal court has unquestioned jurisdiction over one element of the cause -the claim for damages-and can therefore accept jurisdiction of the entire action, ${ }^{244}$ such reasoning would result in denying the injunction, possibly plaintiff's most effective remedy. ${ }^{245}$ Disposition of the action in this manner is subject to the criticism previously directed at the dismissal of claims seeking injunctive relief alone. There would also seem to be no doctrinal warrant for accepting jurisdiction to grant a form of relief otherwise beyond the competence of the court to consider simply because an alternative but cognizable remedy is sought in the same action. ${ }^{248}$ Another approach, apparently adopted in Swift \& Co. v. United Packinghouse Workers, ${ }^{247}$ would deny plaintiff's motion to remand the entire action to the state court and condition remand of the claim for injunction on plaintiff's ability to recast the complaint so as to present separate causes of action for damages and an injunction. ${ }^{248}$ The

243. Swift \& Co. v. United Packinghouse Workers, 177 F. Supp. 511 (D. Colo. 1959).

244. See supra note 194 and accompanying text.

245. Ibid. Cox, Current Problems in the Lawe of Grievance Arbitration, 30 Rocky MT. L. Rev. 247, 255 (1958) ; see also Meltzer, The Supreme Court, Congress, and State Jurisdiction Over Labor Relations: II, 59 CoLUM. L. REv. 269, 281 (1959).

246. The doctrine of pendent jurisdiction would seem inapplicable in this context. See Hurn v. Oursler, 289 U.S. 238 (1933). Lewin, The Federal Courts' Hospitable Back Door -Removal of "Separate and Independent" Non-Federal Causes of Action, 66 HARv. L. REv. 423 (1953). This doctrine allows a federal court to accept jurisdiction of a claim otherwise not properly before the court so long as the claim is immediately joined with a cause of action over which jurisdiction may be independently asserted and arise from the same factual situation. Pendent jurisdiction is thus a means of invoking federal jurisdiction over a claim which independently is neither based on diversity nor raises a federal question. But the jurisdictional defect under Norris-LaGuardia is not the lack of a federal question or diversity but is an express congressional denial of competence to adjudicate. The doctrine of pendent jurisdiction should not be stretched so far as to permit a claim which Congress has expressly denied federal courts the power to adjudicate to ride the jurisdictional coattails of a cognizable claim. Furthermore, a court which accepted jurisdiction of such a mixed cause of action, only to dismiss the injunction claim, would in effect be splitting the action on the basis of the remedy sought, retaining that aspect over which it had jurisdiction and dismissing that segment as to which it never had jurisdiction in any realistic sense. The only authority for a federal court to split a cause of action upon removal is found in 28 U.S.C. $\$ 1441$ (c), a provision inapplicable here since it is geared to "separate and independent" causes of action, not to separate remedies. It is doubtful if the elements of breach of contract can constitute more than one cause of action. But cf. Swift \& Co. v. United Packinghouse Workers, 177 F. Supp. 511 (D. Colo. 1959). See also notes 247-48 infra and accompanying text.

247. 177 F. Supp. 511 (D. Colo. 1959).

248. The complaint in the Swift case was so framed as to raise the possibility of presenting causes of action under state law based on conspiracy to violate the collective bargaining agreement. Id. at 512 (1959). The fact that the employer's claim was not based solely on breach of contract may have been determinative of the court's disposition of the action. 
better approach in cases where the cause could not properly be split into separate causes of action for damages and injunctive relief or where the plaintiff is unwilling to drop the injunction claim is to remand the entire case on the ground that the principal relief sought is an injunction. Under this disposition, the plaintiff would not be denied the opporunity to obtain effective relief and the removal doctrine would not be used as a device for denying sub silentio state injunctive relief.

STEPHEN L. Dinces $\dagger$

†Third year student, Yale Law School. 